\title{
African Archaeological Review \\ Kitala Ware: A New Early Iron Age Pottery Group from the Lower Congo Region in Central Africa \\ --Manuscript Draft--
}

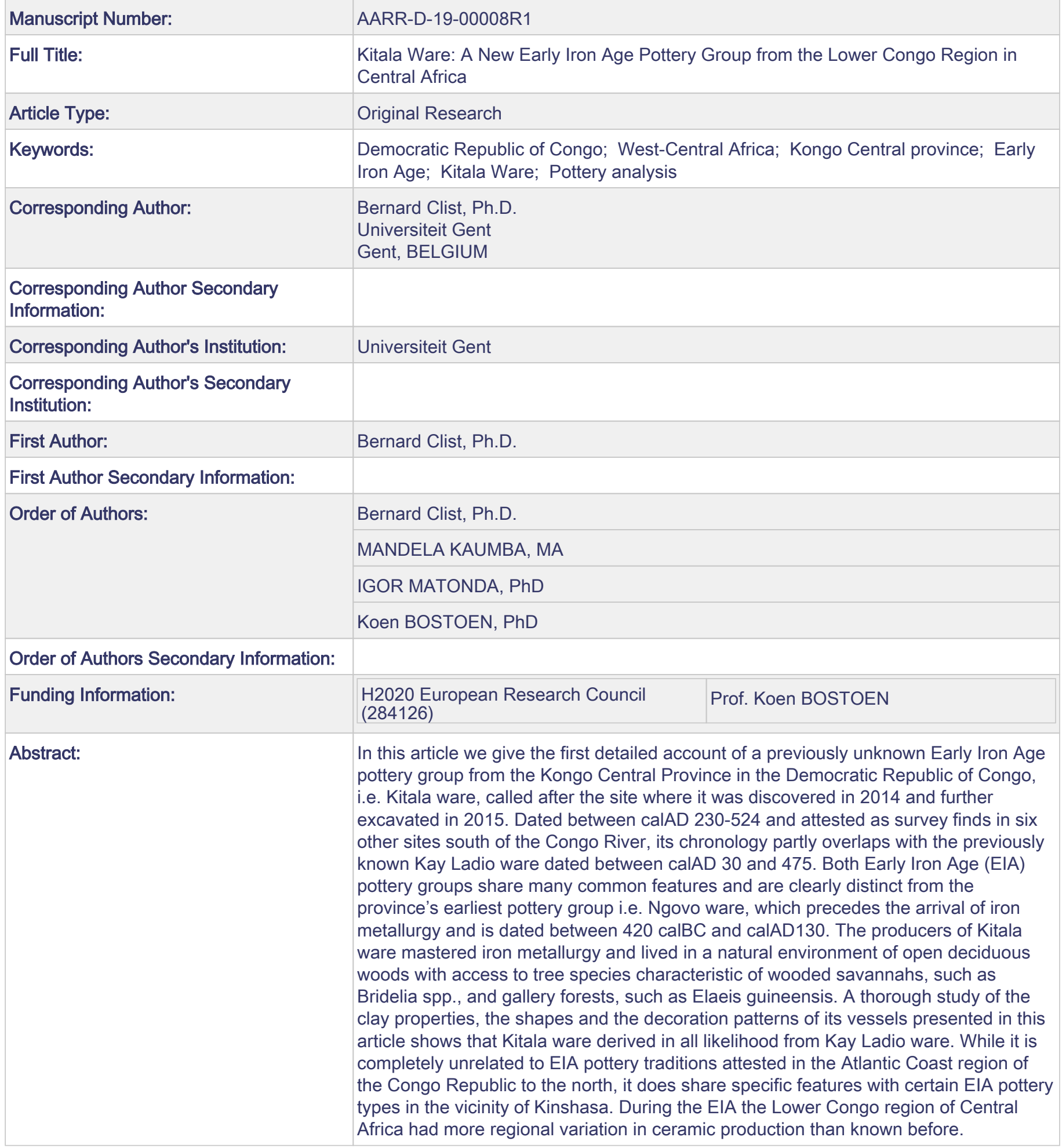




\title{
Kitala Ware: A New Early Iron Age Pottery Group from the Lower Congo Region in Central Africa
}

\section{Bernard CLIST ${ }^{1,2}$, MANDELA KAUMBA ${ }^{1}$, IGOR MATONDA $^{3}$ \& Koen BOSTOEN ${ }^{1}$}

1: BantUGent - UGent Centre for Bantu studies, Department of Languages and Cultures, Ghent University, Belgium

2: Institut des Mondes Africains (IMAF), Paris, France

3: University of Kinshasa (UNIKIN)

\section{Corresponding author}

B. Clist, Academic email: bernardolivier.clist@ugent.be, Ghent Business phone: +32 (0)9 2643845

\section{Archaeological time period}

Early Iron Age, calAD 30-524

\section{Country and region discussed}

Democratic Republic of Congo, Central Africa

\begin{abstract}
In this article we give the first detailed account of a previously unknown Early Iron Age pottery group from the Kongo Central Province in the Democratic Republic of Congo, i.e. Kitala ware or pottery group, called after the site where it was discovered in 2014 and further excavated in 2015. Dated between calAD 230-524 and attested as survey finds in six other sites south of the Congo River, its chronology partly overlaps with the previously known Kay Ladio ware dated between calAD 30 and 475. Both Early Iron Age (EIA) pottery groups share many common features and are clearly distinct from the province's earliest pottery group i.e. Ngovo ware, which precedes the arrival of iron metallurgy and is dated between 420 calBC and calAD130. The producers of Kitala ware mastered iron metallurgy and lived in a natural environment of open deciduous woods with access to tree species characteristic of wooded savannahs, such as Bridelia spp., and gallery forests, such as Elaeis guineensis. A thorough study of the clay properties, the shapes and the decoration patterns of its vessels presented in this article shows that Kitala ware derived in all likelihood from Kay Ladio ware. While it is completely unrelated to EIA pottery traditions attested in the Atlantic Coast region of the Congo Republic to the north, it does share specific features with certain EIA pottery types in the vicinity of Kinshasa. During the EIA the Lower Congo region of Central Africa had more regional variation in ceramic production than known before.
\end{abstract}

Revised paper for publication in the African Archaeological Review (June 20, 2019) 


\section{Keywords}

Democratic Republic of Congo - West-Central Africa - Kongo Central province - Early Iron Age -Kitala ware or pottery group - Pottery analysis

\section{Introduction}

After several decades of stagnation, the archaeology of Central Africa's Lower Congo region has recently got a boost through several research programs pertaining to the history of the Kongo Kingdom, such as the Mbanza Kongo UNESCO World Heritage Project (cf. Clist et al. 2015d; da Piedade Jesus et al. 2016), Geoffroy Heimlich's rock art project (cf. Heimlich et al. 2013, 2018; Heimlich 2014, 2016) and the KongoKing project (cf. Clist et al. 2015b; Clist et al. 2015c; Clist et al. 2018f). Although this recent research in historical archaeology has mainly contributed to a better understanding of the area's Late Iron Age (LIA), it has also generated new insights into the Early Iron Age (EIA) and the period of the first settlements immediately preceding it. This is especially the case of the KongoKing project, which focused on the LIA of the DRC's Lower Congo Province and Northern Angola, i.e. between ca. calAD 1200-1800, but collected also new EIA data in an attempt to establish a sound and continuous chrono-cultural sequence bridging the existing gap between EIA and LIA. Thanks to the 53 new ${ }^{14} \mathrm{C}$ dates obtained through the KongoKing project, the region's chronology has become much more precise, even if there are still very few dates (i.e. 3 only) available between calAD 340-730 (Lv-168) and calAD 1275-1390 (Poz-80292) (Clist 2018); all radiocarbon dates are presented as calibrated with the Calib 7.0.4 software, using the southern hemisphere tables and a 2-sigma range. The $\mathrm{Bu}$, Kindu and Mantsetsi sites in the Kongo Central Province of the Democratic Republic of the Congo (DRC) yielded, both north and south of the Congo River, new attestations of the earlier documented EIA "Kay Ladio" pottery, whose time range was redefined at calAD 30-475 (Clist et al. 2019b). However, KongoKing research has also led to the discovery of new EIA pottery groups, such as the Kitala ware or pottery group, which is the main focus of the present article. Being slightly younger than Kay Ladio ware (i.e. calAD 230-524) and found only south of the Congo River, Kitala ware indicates that the Lower Congo region of Central Africa had more regional variation in ceramic production during the EIA than known before. For a first global assessment of the new data available on the area's EIA, see Clist et al. (2018e).

Within the current-day Kongo Central Province of the DRC, formerly called "BasCongo", the oldest pottery group is known as Ngovo ware, dated between about 420 calBC and calAD 130 (de Maret 1986; Clist et al. 2018e: 46). All its remains have been found on the south bank of the Congo River and further south towards the border with the Angola Republic, in open-air sites, such as Sakuzi, as well as in caves and rock shelters, such as Dimba (Clist 1982: 134-146; de Maret 1986). According to the current state of knowledge, the producers of Ngovo ware belonged to the oldest sedentary communities of the Kongo Central Province. They settled there before the advent of iron metallurgy. Besides this very characteristic pottery, their industry included polished stone axes and hoes. Identical axes were surface-collected in the vicinity of Mbanza Kongo in northern Angola (Ervedosa 1980: 166-170;

Revised paper for publication in the African Archaeological Review (June 20, 2019) 
Clist \& Lanfranchi 1992: 246-248; de Matos et al. 2013). Although these tools were not found in association with Ngovo ware, they could suggest that this ceramic group did extend south of the present-day Angola-Congo border. Future research in Angola should point out whether this is really the case. Recent fieldwork along the Atlantic coast north of the Congo mouth, i.e. around Muanda (DRC), did not result in any finds of Ngovo ware according to our preliminary analyses (Clist et al. 2019a).

The first pottery group associated with iron metallurgy in Kongo Central Province is the aforementioned Kay Ladio ware, which is stylistically distinct from Ngovo ware and whose time range has been determined at calAD 30-475 (de Maret 1990; Clist et al. 2018e: 49-50; Clist et al. 2019b). Its producers still used stone hoes and polished stone axes, possibly only for symbolic purposes, but also transformed iron ore near their settlement as documented, for instance, at the Kindu site. Unlike Ngovo ware, Kay Ladio has always been uncovered at open-air sites. Moreover, it is much more widespread than Ngovo ware. It has not only been found south of the Congo River, but also north of it, even into Congo-Brazzaville (Clist 1982: 147-158; Dupré \& Pinçon 1997: 42-43; Clist et al. 2018e: 48). Given the recent discovery of this type of pottery on several sites around Nduizi (formerly called Kongo dia Vanga) at some 12 to 6 kilometers north of the Angola-Congo border (Clist et al. 2019a), Kay Ladio ware possibly also extends into northern Angola. An indirect indication for the extension of Kay Ladio ware into present-day Angola is the characteristic pottery from the Cabolombo site south of Luanda (Angola) (Ervedosa 1980; Da Silva Domingos 2009; Valdeyron \& Da Silva Domingos 2012). Cabolombo pottery is very similar to Kay Ladio ware in terms of shapes and decoration patterns and its time range, based on three ${ }^{14} \mathrm{C}$ dates, falls within that of Kay Ladio, i.e. calAD 128-428 (Clist et al. 2018e: 46-47). With regard to the possible southward expansion of Kay Ladio ware, it is striking that this distinctive pottery group has never been found further east. It is entirely absent from the two archaeologically best-documented areas in the eastern part of the Kongo Central Province, i.e. the basin of the Inkisi River where the KongoKing project team carried out extensive prospections and excavations between 2012 and 2015 (Clist et al. 2018a; Clist et al. 2018b; Clist et al. 2018c) and the wider Kinshasa region (Clist et al. 2018e: 49-50). Our recent fieldwork in the vicinity of Muanda did also not lead to any finds of Kay Ladio ware, as far as we can tell from a first study of the material (Clist et al. 2019a), but EIA research on the Atlantic coast of the DRC is still embryonic.

Figure 1 presents the sites in the Kongo Central Province where Ngovo and Kay Ladio wares have been found so far. It shows that these two ancient ceramic groups, which are chronologically disparate, also have a partially complementary distribution. So far, no site has yielded attestations of both types of pottery in the same pits. South of the Congo River, only one site has yielded excavated attestations of both Ngovo ware and Kay Ladio ware: Sakuzi. Associated surface finds of Ngovo and Kay Ladio wares occur on the following sites: Kay Ladio, Kibula, Kondo, and Mabulu, all situated in the close vicinity of Sakuzi, as well as Mbanza 2 and Mongo.

\section{Insert Figure 1 here}


It is against this background that we present here a new EIA pottery group from the Kongo Central Province, i.e. Kitala ware, for which only preliminary analyses are available so far (Clist et al. 2018e: 50). This EIA ceramic group has been called after the eponymous site near the modern village of Mbanza Mpangu. In $§ 2$, we present the Kitala site. In $§ 3$, we give a detailed description of Kitala ware. In $\S 4$, we offer a comparative study of Kitala ware. Conclusions follow in $\S 5$.

\section{The site of Kitala}

In this section, we describe the archaeological site where Kitala ware was first discovered. We present its geographical, geological and paleo-environmental setting in $\$ 2.1$. In $\$ 2.2$, we give a short account of the excavations carried on the site since 2014 . We describe its stratigraphy in $\$ 2.3$, its chronology in $\$ 2.4$ and the material culture it yielded apart from pottery in $\S 2.5$.

\subsection{Geographical, geological and paleo-environmental setting}

The Kitala site (S05 $33^{\prime} 03^{\prime \prime}$; E14 $\left.{ }^{\circ} 52^{\prime} 04^{\prime \prime}\right)$, situated to the north of the modern village of Mbanza Mpangu, is located on an elongated and heavily eroded hill with a fairly large summit area culminating at 468 meters above sea level. A GIS-based topographic map of the area, of which Figure 2 is an extract, was developed in close collaboration with the Geography Department of Ghent University. It was linked to different layers of information, such as patterns of land use and the archaeological potential of hilltops based on an analysis of aerial and satellite photography (Vergaert 2014), which were of great help for our surveys and subsequent excavations.

\section{Insert Figure 2 here}

The geological substratum of the Kitala site is composed of Precambrian schist-limestone from the Lukunga array. Around Mbanza Mpangu and the Kitala site, the underground consists of limestones and various dolomites, generally clayey, with abundant calcschists and cherts (Delmoitie-Nicolaï et al. 1972). As shown on Figure 2, the Bombe River cut itself a way through the limestone massif, which is home to several narrow galleries used until today as temporary shelters for hunters. Alluvial deposits at the bottom of the valley can reach an effective width of 800 to 1000 meters and a thickness of up to 3 meters. This alluvium explains the presence of large agricultural plots on both banks of the river (Figure 2). Their soils are irrigated and further enriched thanks to the river's annual flood. Nowadays the whole floodplain around Mbanza Mpangu is intensively exploited, and the villages are situated above the limit of the annual inundation of the rainy season. Its rich lands may have attracted people during the Early Iron Age too, as is suggested by the fact that the ancient Kitala settlement is also situated in the floodplain in a similar position as the modern villages. 
The Kitala site is situated today in a natural environment of open deciduous woods with tree species that are characteristic of wooded savannahs and gallery forests (Figure 2). As shown by Hubau et al. (2018) through a preliminary analysis of charcoals, the vegetation around Kitala was probably also dominated by savannah species at the time of the EIA settlement. Moreover, the charcoal assemblage of Kitala is strikingly less diverse in species than those analyzed for the EIA sites of Bu 3 and Kindu (Hubau et al. 2018: 29, Table 4.3). This could reflect either a more selective harvest process or a natural environment that was poorer in species. One of the taxa abundantly present in the Kitala charcoal sample is Bridelia spp., which is a typical savannah species (Lebrun \& Gilbert 1954; Compère 1970). Still today, several Bridelia species, such as Bridelia micrantha and Bridelia ferruginea, have an array of uses in medicine, building, cooking and pigment fabrication in the Kongo Central Province (Latham 2004: 59-60). Other common taxa in the charcoal record, such as Beilschmiedia spp. and Irvingia smithii, were probably collected in gallery forests. The economic importance of those gallery forests is also apparent from the remarkable abundance of endocarp fragments of the oil palm (Elaeis guineensis) at Kitala, which could suggest that villagers intensively exploited and maybe protected nearby palm groves.

\subsection{Excavations}

In 2014, Igor Matonda and Els Cranshof, two former PhD students of the KongoKing project, discovered the Kitala site, while they conducted surveys in the vicinity of the modern village of Mbanza Mpangu in an attempt to locate the capital of the Kongo kingdom's former Mpangu province (Matonda et al. 2014: 59-60). They dug five trenches, four of $1 \mathrm{~m}^{2}$ (trenches 1-2 \& 4-5) and one of $2 \mathrm{~m}^{2}$ (trench 3 ) in the area of the hilltop where they had found surface concentrations of pottery. The excavation unit was the square meter and spits of $20 \mathrm{~cm}$. In trenches 4 and 5 , they hit a layer of gravel at $-60 \mathrm{~cm}$ and stopped excavating there. In trenches 1-3 they uncovered refuse pits containing large amounts of archaeological material such as charcoal, charred palm nuts, pottery, and iron slag. An archaeobotanical sample extracted from trench 3 and analyzed in the field in 2014 turned out to be sterile. The recent flotation of another sample from trench 3 as well as one from trench 6 (2015) in the African Archaeology and Archaeobotany lab of Frankfurt Goethe University has yielded the same result.

In 2015 Els Cranshof and Igor Matonda further excavated Kitala, this time together with Bernard Clist and Mandela Kaumba, another former PhD student of the KongoKing project (Clist et al. 2015a: 129-131). This excavation spanned a surface of $9 \mathrm{~m}^{2}$ spread over 3 trenches (2, 3, and 6). Two of the trench pits of the 2014 campaign were revisited and expanded by $4 \mathrm{~m}^{2}$ (trench 2) and $1 \mathrm{~m}^{2}$ (trench 3), while a new one (trench 6) of $4 \mathrm{~m}^{2}$ was opened. The excavation unit was the square meter again but now spits of $10 \mathrm{~cm}$.

\section{Insert Figure 3 here}

The excavations of 2014 and 2015 accumulate to a total of $15 \mathrm{~m}^{2}$ and led to the identification of three cultural components: Late Stone Age (LSA) (cf. §2.5.1), EIA and a tomb from 
historical times. This grave probably dates back to the $19^{\text {th }}-20^{\text {th }}$ centuries (cf. $\S 2.4$ ). It was possibly part of a larger cemetery forgotten about by the present-day villagers. However, it could also be an isolated burial, as these have been reported for Kongo people with high social status since the late $19^{\text {th }}$ century (see for instance Weeks 1914: 274-275; Decapmaker 1951: 126).

\subsection{Stratigraphy}

All trenches have the same stratigraphy. Below the very dark gray humus (5YR 3/1) (i.e. layer 1 in Figure 4), a settlement level embedded in a wet dark reddish brown clayey sand (5YR 2.5/2) (i.e. layer 2 in Figure 4) is situated between $-20 \mathrm{~cm}$ and $-30 \mathrm{~cm}$ on top of a thick brownish yellow clayey sand level (10YR 6/8) (i.e. layer 3 in Figure 4). The surface exposure and shallow depth of the occupation layer dated to about calAD 400 hints to severe erosion since then. Below layer 3, starting at around $-80 \mathrm{~cm}$, a gravel of heterogeneous module (i.e. layer 6 in Figure 5). This gravel is the upper part of the mother rock (alteration level), which is clearly visible in the section of a small tributary of the Bombe at a short distance from the archaeological site. On the gravel, between $-80 \mathrm{~cm}$ and $-120 \mathrm{~cm}$ depending on the trench, a few stone tools manufactured out of a grey chert have been found.

\section{Insert Figures 4 \& 5 here}

Several small pits were dug from the settlement layer containing Kitala ware (i.e. layer 4, filling of a pit, in Figure 5) cutting through the lower level composed of a yellowish compact clay (i.e. layer 5 in Figure 5), and sometimes through the upper part of the cemented gravel (i.e. layer 6 in Figure 5). The heavily weathered pottery formed a real deposit layer (cf. Figures 4 and 6). This layer was sometimes visible on the surface, but was generally buried at up to $-30 \mathrm{~cm}$ (i.e. layers 1 and 2 in Figure 4). Both careful typological analysis of all potsherds and the few possible refits between pottery fragments from the pits and from the layer point out that the artefacts originate from a single cultural component.

\section{Insert Figure 6 here}

\subsection{Chronology}

The site's chronology is well determined by four AMS ${ }^{14} \mathrm{C}$ dates, all of which were obtained from charcoal. The calibrations were carried out at 2-sigma precision, using Calib7.0.4 software and the calibration tables of the southern hemisphere. Three of the ${ }^{14} \mathrm{C}$ dates turned out to be contemporaneous:

- Poz-69263 2230+/-30 bp (cal. to 366-151 calBC), trench 2 2014, square A1, -33cm;

- Poz-69053 1665+/-30 bp (cal. to 369-524 calAD), trench 3 2014, square B1, -28cm; 
- Poz-75419 1710+/-30 bp (cal. to 250-435 calAD), trench 2 2015, square A2, -44cm in refuse pit 1 ;

- Poz-75420 1680+/-30 bp (cal. to 345-523 calAD), trench 62015 , square A'1, -50/-60 cm in refuse pit 1.

One could think of four possible explanations to account for the discrepancy of 500 years between the first date and the three other ones, but we realize that none of them is entirely convincing.

A first possible explanation is that the older charcoal sample (Poz-69263) was embedded in the EIA settlement layer by way of water runoff during the rainy season. However, this would imply that further uphill there was an earlier settlement whose pottery was not found during our surveys, which would be surprising. It also could have originated from an ancient natural bush fire.

A second explanation could be that producers of Kitala ware occupied the site since the third century BC. However, that would mean not only that Kitala ware did almost not evolve over a period of nearly half a millennium, but also that it is actually older than EIA Kay Ladio ware and synchronous with pre-EIA Ngovo ware, while we have good typological reasons to assume that this is not the case (cf. §4).

A third possible explanation is that EIA refuse pits were dug into the LSA occupation layer (e.g. Figure 5, trench 6). As mentioned above, a small number of stone artifacts, probably of LSA origin, were discovered at around $-80 \mathrm{~cm}$ to $-100 \mathrm{~cm}$ on top of the gravel layer. However, this would imply that this pre-ceramic LSA component is less than 2500 years old and thus roughly contemporaneous with the Ngovo ware component attested elsewhere in the Kongo Central Province. This is not unconceivable, but still rather unlikely, if one takes into account that similar Stone Age tools found in the vicinity of Kinshasa are older than 5000 years (cf. §2.5.1).

The last explanation, and maybe the most convincing one for the time being, is that the older ${ }^{14} \mathrm{C}$ date (Poz-69263) is not reliable. The original date of the selected charcoal sample may have been skewed due to its exposure to water leakage. Given that it was dug up near the surface, where it possibly was in contact with rootlets of savannah grasses, such an alteration cannot be excluded, even if the Poz-69053 ${ }^{14} \mathrm{C}$ date is based on charcoal collected in similar conditions and does fit the two other ${ }^{14} \mathrm{C}$ dates (Poz-75419 and Poz-75420).

Whatever the right explanation might be, we discard for the time being the deviant Poz-69263 ${ }^{14} \mathrm{C}$ date because it is isolated. Hence, we date the settlement layer containing Kitala ware between calAD 250 and 524 on the basis of the three remaining and contemporaneous ${ }^{14} \mathrm{C}$ dates.

For the dating of the tomb in trench 6 , the Kidd \& Kidd Type Ic hexagonal blue glass beads, which were found at the bottom of the burial filling together with some teeth fragments, can be used as terminus post quem. This type of bead was commonly produced in Bohemia between 1803 and 1860 (cf. Coccato et al. 2017; Karklins \& Clist 2018), but it remained popular in Africa for much longer (K. Karklins, personal communication). 


\subsection{Material culture}

In this section, we present the material culture other than ceramics that was uncovered at the Kitala site: lithics representing the site's LSA component in \$2.5.1 and evidence for iron metallurgy as part of the site's EIA component in $§ 2.5 .2$.

\subsubsection{Lithics}

The Kitala site yielded 28 stone artifacts originating from 6 squares in 3 different trenches. 21 of them were found between $-80 \mathrm{~cm}$ and $-120 \mathrm{~cm}$ lying on the gravel layer. Relying on the low density of flakes that were knapped from at least two different non-quartz rocks and have a microlithic outlook and a pressured retouch, we have previously attributed this assemblage to the LSA (Clist et al. 2015a: 130). Cornelissen (2018: 38) has identified 23 of the Kitala stone artifacts as being made out of grey chert, 8 of which having retained porous cortex. The biggest piece in chert is a flaked core of $4 \mathrm{~cm}$, the maximal dimension of the other being $2.2 \mathrm{~cm}$ on average. Among the pieces of modified chert, there is a lozenge-shaped bifacial arrowhead $(3,2 \times 1,8 \times 0,5 \mathrm{~cm})$ without cortex, the middle part of another lozenge shaped bifacial arrowhead, a transverse arrowhead, two borers, and one small elongated flake with a retouched side.

Kitala's LSA assemblage was not radiocarbon-dated, but an approximate timeframe could be proposed through comparison with similar industries from the region. The coexistence of these tool types is attested on the Bateke Plateau, at the Dimba cave in the Kongo Central Province and in the Kinshasa plain. On the Bateke plateau, the microlithic tools knapped from polymorphic sandstones are not directly dated (Cahen \& Mortelmans 1973: 22; Muya wa Bitanko Kamuanga 1991: 120). At the Dimba cave, similar types of tools are found in the so-called "Dimba III" component which was not radiocarbon-dated (Lavachery 1990: 95-96 in vol.91; fig.VII in vol.92). They are mostly made out of either chalcedony $(60 \%)$ or polymorphic sandstone (25 to $29 \%$ ) (Cornelissen 2018 : 43 ). The only radiocarbon-dated assemblages containing stone tool types similar to the ones found in the Kitala come from the Kinshasa plain and go back to the so-called "Late Tshitolean" period. They have been dated to ca. 5,474-4,850 calBC (Lv-289) at Kizenzu, to ca. 5,205-4,262 calBC (Lv-45) and ca. 4,791-4,344 calBC (Lv-162) at Mount Gafula (Van Moorsel 1968: 221; Cahen \& Mortelmans 1973: 38). In terms of chronology, it is also interesting to note that the Kitala stone tools bear no resemblances to the quartz tools found at the nearby Ngongo Mbata site (Cornelissen 2018: 35-36), which have been dated to 8,229-7,795 calBC (Poz80297) and 9,112-8,559 calBC (Poz-60770) (Clist 2018: 232-233).

\subsubsection{Iron metallurgy}

Fragments of tuyeres and iron slag have been recovered from all trenches excavated in 2014 and 2015 (cf. Tables 1 and 2). Their depth distribution clearly corresponds with that of the pottery. Most of iron artifacts have been found between the surface and $-30 \mathrm{~cm}$. Below that 
depth, they were found in the fillings of refuse pits. Iron slag, either small ( $3 \times 3 \mathrm{~cm}$ or smaller) or large $(7 \times 7 \mathrm{~cm}$ or smaller), is found at the same depth.

The internal diameter of none of the tuyeres could be measured. 5 out of 19 tuyeres fragments were covered with slag indicating that they were part of the extremity positioned towards or inside the furnace. Macroscopic examination of the slag and the tuyeres by Caroline Robion-Brunner from the TRACES laboratory (CNRS UMR 5608) has pointed out that the slag is typical of a forge. Its presence amongst domestic refuse is not surprising and suggests that the smelting site is still to be found, probably in close proximity to the settlement.

\begin{tabular}{|l|c|c|c|}
\hline Depth (cm) & $\mathbf{3 0 x 3 0 m m}$ & $\mathbf{7 0 x 7 0 m m}$ & Total \\
\hline $0 /-10$ & 4 & 1 & $\mathbf{5}$ \\
\hline$-10 /-20$ & 5 & 2 & $\mathbf{7}$ \\
\hline$-20 /-30$ & 4 & 1 & $\mathbf{5}$ \\
\hline$-30 /-40$ & 1 & 0 & $\mathbf{1}$ \\
\hline$-40 /-50$ & 1 & 0 & $\mathbf{1}$ \\
\hline$-50 /-60$ & 0 & 0 & $\mathbf{0}$ \\
\hline$-60 /-70$ & 0 & 0 & $\mathbf{0}$ \\
\hline$-70 /-80$ & 0 & 0 & $\mathbf{0}$ \\
\hline$-80 /-90$ & 0 & 0 & $\mathbf{0}$ \\
\hline$-90 /-100$ & 0 & 0 & $\mathbf{0}$ \\
\hline$-100 /-110$ & 0 & 0 & $\mathbf{0}$ \\
\hline Total & $\mathbf{1 5}$ & $\mathbf{4}$ & $\mathbf{1 9}$ \\
\hline
\end{tabular}

Table 1: Tuyeres fragments size, numbers and position

\begin{tabular}{|l|c|c|c|c|}
\hline Depth (cm) & $\mathbf{3 0 x 3 0 m m}$ & $\mathbf{7 0 x 7 0 m m}$ & $\mathbf{1 2 0 \times 1 2 0 m m}$ & Total \\
\hline $0 /-10$ & 23 & 15 & 0 & $\mathbf{3 8}$ \\
\hline$-10 /-20$ & 45 & 14 & 0 & $\mathbf{5 9}$ \\
\hline$-20 /-30$ & 96 & 36 & 1 & $\mathbf{1 3 3}$ \\
\hline$-30 /-40$ & 18 & 1 & 0 & $\mathbf{1 9}$ \\
\hline$-40 /-50$ & 5 & 3 & 0 & $\mathbf{8}$ \\
\hline$-50 /-60$ & 3 & 2 & 0 & $\mathbf{5}$ \\
\hline$-60 /-70$ & 0 & 0 & 0 & $\mathbf{0}$ \\
\hline$-70 /-80$ & 0 & 0 & 0 & $\mathbf{0}$ \\
\hline$-80 /-90$ & 3 & 0 & 0 & $\mathbf{3}$ \\
\hline$-90 /-100$ & 0 & 0 & 0 & $\mathbf{0}$ \\
\hline$-100 /-110$ & 1 & 0 & 0 & $\mathbf{1}$ \\
\hline Total & $\mathbf{1 9 4}$ & $\mathbf{7 1}$ & $\mathbf{1}$ & $\mathbf{2 6 6}$ \\
\hline
\end{tabular}

Revised paper for publication in the African Archaeological Review (June 20, 2019) 
Table 2: Iron slag size, numbers, and position

The only iron implement found at Kitala is a large fragment of a knife with a long tang (Figure 7). It was found at $-24 \mathrm{~cm}$ deeply buried in the single archaeological layer also containing pottery and can therefore be considered as belonging to the site's EIA component.

\section{Insert Figure 7 here}

\section{Descriptive account of Kitala ware}

As shown in Table 3, the Kitala site yielded more than 3,800 potsherds. Most of them were spread out as a real carpet forming a distinct archeological layer that started slightly under the surface and reached a depth of $-40 \mathrm{~cm}$. The sherds not being part of that carpet are very low in quantity and have been found in the refuse pits where they have a vertical distribution between $-40 \mathrm{~cm}$ and $-120 \mathrm{~cm}$.

\begin{tabular}{|l|c|c|c|c|c|c|c|}
\hline \multirow{2}{*}{ Depth } & \multicolumn{3}{|c|}{ Decorated sherds } & \multicolumn{3}{c|}{ Undecorated sherds } & \multirow{2}{*}{ Total } \\
\cline { 2 - 7 } & $\mathbf{3 x 3 c m}$ & $\mathbf{7 \times 7} \mathbf{c m}$ & $\mathbf{1 2 \times 1 2} \mathbf{c m}$ & $\mathbf{3 \times 3 c m}$ & $\mathbf{7 \times 7} \mathbf{c m}$ & $\mathbf{1 2 \times 1 2} \mathbf{c m}$ & \\
\hline $0 /-20 \mathrm{~cm}$ & 418 & 432 & 9 & 909 & 186 & 0 & $\mathbf{1 9 5 4}$ \\
\hline$-20 / 40 \mathrm{~cm}$ & 382 & 325 & 6 & 761 & 232 & 4 & $\mathbf{1 7 1 0}$ \\
\hline$-40 / 60 \mathrm{~cm}$ & 9 & 6 & 0 & 43 & 1 & 0 & $\mathbf{5 9}$ \\
\hline$-60 / 80 \mathrm{~cm}$ & 3 & 0 & 0 & 19 & 0 & 0 & $\mathbf{2 2}$ \\
\hline$-80 / 100 \mathrm{~cm}$ & 18 & 9 & 0 & 54 & 0 & 0 & $\mathbf{8 1}$ \\
\hline$-100 / 120 \mathrm{~cm}$ & 0 & 0 & 0 & 4 & 0 & 0 & $\mathbf{4}$ \\
\hline Total & $\mathbf{8 3 0}$ & $\mathbf{7 7 2}$ & $\mathbf{1 5}$ & $\mathbf{1 7 9 0}$ & $\mathbf{4 1 9}$ & $\mathbf{4}$ & $\mathbf{3 8 3 0}$ \\
\hline
\end{tabular}

Table 3: Size, numbers and depth of potsherds

In the following paragraphs we describe Kitala ware in terms of fragmentation ( $\$ 3.1)$, hardness (\$3.2), thickness (§3.3), clay colors ( 3.4$)$, clay fabrics (§3.5), clay weathering (§3.6), shapes $(\S 3.7)$ and decoration $(\S 3.8)$.

\subsection{Fragmentation}

As shown in Table $3,68.4 \%$ of the sherds are $3 \times 3 \mathrm{~cm}, 31.3 \% 7 \times 7 \mathrm{~cm}$, and only $0.3 \%$ $12 \times 12 \mathrm{~cm}$. We did not find a sherd having a diameter larger than $12 \mathrm{~cm}$. The relative small size of the sherds indicates that the pottery was trampled on a settlement floor. Efforts to conjoin pottery fragments did not work out in most cases. 


\subsection{Hardness}

All pottery is of intermediate hardness. In most cases, the clay can be scraped with the fingernail and in some cases it can even be easily crushed. None of the sherds can only be scraped with an iron tip.

\subsection{Thickness}

The thickness of individual sherds ranges between $4 \mathrm{~mm}$ and $34 \mathrm{~mm}$, which is quite an interval. The range diminishes, however, if one distinguishes between pot bases, bodies and necks. The 16 sherds that can clearly be identified as originating from the base of a pot mostly have a thickness between $9 \mathrm{~mm}$ to $12 \mathrm{~mm}$ ( 9 items), but some are much thicker, i.e. $15 \mathrm{~mm}$ ( 2 items), $17 \mathrm{~mm}$ ( 2 items), 20mm ( 1 item), $26 \mathrm{~mm}$ ( 1 item) and $34 \mathrm{~mm}$ (1 item). The thickness of sherds from the body of a pot mostly varies between $4 \mathrm{~mm}$ and $12 \mathrm{~mm}$ with two peaks at $7 \mathrm{~mm}$ and $10 \mathrm{~mm}$ (44 items), except for 6 items ranging between $14 \mathrm{~mm}$ and $17 \mathrm{~mm}$. Sherds identified as being part the neck (i.e. 61 in total) have a thickness ranging between $5 \mathrm{~mm}$ and $13 \mathrm{~mm}$ with a neat peak at $8 \mathrm{~mm}$ (13 items) and a slightly lower peak at $12 \mathrm{~mm}(8$ items).

\subsection{Clay colors}

All sherd profiles show a black center and fairly thin and clear outer parts. The pottery color was identified using the French Cailleux Code of colors. External colors range from light red (2.5YR 6/8) to dark brown (7.5YR 3/4) through yellowish red (5YR 4/6) and reddish yellow (5YR 6/8). Internal colors vary from red (2.5YR 5/8) to reddish brown (5YR 4/3), via reddish yellow (7.5YR 6/8). These dark colors indicate a reduction firing carried out in a closed and confined environment without contact with the exterior.

\subsection{Clay fabrics}

We identified five recipes using the protocol developed in Clist (2005: 89-121) on the basis of Orton et al. (1993). After having counted all potsherds, we examined more closely the 131 most characteristic ones, such as lips, bases, profiles and decorated pieces. We consider their ratios to be representative of the whole assemblage. Recipes 1 and 2 below are the most common ones, i.e. $72.5 \%$ and $22.9 \%$ respectively. The other recipes constitute only $4.6 \%$ of the sample.

Recipe 1 (95 items): diameter of grains between $0.5 \mathrm{~mm}$ and $3 \mathrm{~mm}$, density of non-plastic elements $20 \%$ to $30 \%$, coarse to very coarse sorting. The non-plastic elements consist of minerals, which are sometimes accompanied by small vacuoles pointing to the presence of plant elements that disappeared during the firing of the pots. This recipe seems to be associated with the thinnest sherds. 
Recipe 2 (30 items): diameter of grains between $0.5 \mathrm{~mm}$ and $3 \mathrm{~mm}$ but regular presence of minerals considerably exceeding the $3 \mathrm{~mm}$ diameter (i.e. having a surface of up to $6 \times 9 \mathrm{~mm}$ or $5 \times 13 \mathrm{~mm}$ ), density of non-plastic elements $30 \%$, very coarse sorting. Non-plastic elements are essentially minerals. This recipe seems to be associated with the thickest sherds, i.e. mainly bases and necks.

Recipe 3 ( 4 items): profiles with a black center and clear outer parts like all other sherds but with thicker oxidized outer parts, diameter of grains between $0.5 \mathrm{~mm}$ and $2 \mathrm{~mm}$, density of non-plastic elements $10 \%$ to $20 \%$, medium sorting. The non-plastic elements consist of minerals but accompanied by black elements.

Recipe 4 ( 1 item): profile with a black center and clear outer parts like all other sherds but indepth oxidization giving it a reddish outlook, diameter of grains less than $1 \mathrm{~mm}$, density of non-plastic elements $10 \%$, medium to good sorting. The single sherd made according to this recipe also has an exceptional herringbone decoration pattern on the body suggesting that it is an import.

$\underline{\text { Recipe } 5}$ (1 item): profile with a black center and clear outer parts like all other sherds but the oxidized areas are thicker. The average diameter of the grains is between $0.5 \mathrm{~mm}$ and $1 \mathrm{~mm}$ except for some rare fragments of $3 \mathrm{~mm}$, density of non-plastic elements $20 \%$, good sorting.

\subsection{Clay weathering}

The majority of the pottery remains were found in the settlement layer, sometimes eroding out at the surface (cf. Figure 4). The sherds are heavily weathered on the outside due to the mechanical alteration of clays. Given the site's position on a slight slope of the hilltop, this alteration was probably caused by rains and runoff water. $60 \%$ of the sherds are very weathered in that the temper is clearly visible on their entire surface. $36 \%$ of the sherds are partially intact in that the original surface has remained intact in some places, but not in others where the temper is clearly visible. Only on $4 \%$ of the sherds decoration patterns and traces of smoothing, polishing and/or burnishing are more or less intact. Even on weathered potsherds, the decoration can often still be distinguished in grazing light.

\subsection{Shapes}

Four types of vessel shape are attested at the Kitala site: three closed shapes and one open shape.

Among the vessels with a closed shape, we distinguish between pots having an opening diameter of $30 \mathrm{~cm}$ or less (cf. Figure 8, $\mathrm{n}^{\circ} 1$ and 6 ; Figure 9, $\mathrm{n}^{\circ} 4$ ), and jars have an opening diameter of more than $30 \mathrm{~cm}$ (cf. Figure 8, $\mathrm{n}^{\circ} 2$ and 4; Figure 10, $\mathrm{n}^{\circ} 3$ ). Across pots and jars, three types of closed vessels can be identified on the basis of their neck morphology: (1)

Revised paper for publication in the African Archaeological Review (June 20, 2019) 
Type A: pots with a short or short cylindrical neck (cf. Figure 8, $\mathrm{n}^{\circ} 4,6,7$ and 8; Figure 10, $\mathrm{n}^{\circ} 3$ ), (2) Type B: vessels with a concave profile (cf. Figure 8, $\mathrm{n}^{\circ} 6$; Figure $9, \mathrm{n}^{\circ} 2$ and 4 ), and (3) Type C: recipients with a longer cylindrical and straight necks (cf. Figure 8, n 2 ; Figure 9 , $\mathrm{n}^{\circ} 6,9$; Figure $\left.10, \mathrm{n}^{\circ} 1,2\right)$.

Open shapes are poorly represented. The thickness of those vessels seems to co-vary with their opening diameter (cf. Figure 9, $\mathrm{n}^{\circ} 7$ and 8); the larger the volume the thicker the profile. We also observe a correlation with the clay fabrics: recipe 1 seems to be mostly used for thinner vessels with a small opening diameter, while recipe 2 most often occurs with thicker and larger vessels.

The 16 bases (outer part), which we could identify, are flat as are their associated bottoms (inner part) (cf. Figure 11). As already mentioned, their thickness generally varies between $9 \mathrm{~mm}$ and $12 \mathrm{~mm}$. The exceptional cases of up to $34 \mathrm{~mm}$ thick must have belonged to the base of bigger vessels.

The lips are convex and tapering (cf. Figure 8, ${ }^{\circ} 7$; Figure 9, $\mathrm{n}^{\circ} 4$ and 8; Figure 10, $\mathrm{n}^{\circ} 1$ and 4) and sometimes flat, perhaps when originating from thinner vessels (cf. Figure 8, $\mathrm{n}^{\circ} 8$; Figure 9, $n^{\circ} 2$ and 3). Most often they are flat with an internal bevel, sometimes looking like a double bevel (cf. Figure 8, $\mathrm{n}^{\circ} 1-6$; Figure 9, $\mathrm{n}^{\circ} 1,6,9$ and 10). A few lips are formed with a simple bevel (cf. Figure 9, n⿳5口; Figure 10, n²). All the lip bevels are sloping towards the inside.

Finally, it is important to note that a limited of number of neck and body sherds show clear traces of joined coils - oblique, $\mathrm{U}$ and $\mathrm{N}$ shaped breaks - indicating that one of the techniques to shape Kitala ware was coiling, for at least part of the vessel.

\section{Insert Figures 8-11 here}

\subsection{Decoration}

In order to understand the organization of decoration on Kitala ware it is important to realize that the decorated items represent $42.2 \%$ of the total number of sherds collected. Given this proportion, decoration cannot have been limited to the upper part of the vessels as is often the case. On the other hand, decoration covering the entire pot can also not have been the rule.

The decoration tools are limited to single-point sticks and combs with 4 or 5 teeth. These combs were either superficially dragged on the surface to form traces (e.g. Figure 8, $\mathrm{n}^{\circ} 1$ and 2 ) or more deeply to form several types of patterns (e.g. Figure 11, $\mathrm{n}^{\circ} 4-6$ ). The single-point sticks appear to have been used for the tracing of various compositions (e.g. Figure $8, \mathrm{n}^{\circ} 6$; Figure $10, \mathrm{n}^{\circ} 1$ ), and for impressions organized in several rows (e.g. Figure 10, $\mathrm{n}^{\circ} 4,6$ ) or in a single row (e.g. Figure $9, n^{\circ} 5$ ).

The different decorative elements combine into several decorative units. The type of decorative unit used seems to depend on the position on the vessel. The upper parts (i.e. lips and necks), the middle parts and the bases of vessels are decorated differently.

Out of a total of 47 upper part sherds only 8 (i.e. 17\%) have a decorated lip, 6 of which are illustrated (Figure 9, $\mathrm{n}^{\circ} 1-6$ ). Lip decorations are not common and do not follow a 
standardized system. Each lip is treated differently, with incisions or impressions using sticks: short incisions or impressions on the lip surface (cf. Figure 9, $\mathrm{n}^{\circ} 3$, 4), short incisions or impressions on the inner surface (cf. Figure 9, $\mathrm{n}^{\circ} 1,2,5,6$ ) or outer surface (cf. Figure 9, $\mathrm{n}^{\circ} 5,6$; Figure 10, $\mathrm{n}^{\circ} 4$ ).

Only one of the 47 upper part sherds has an undecorated neck. The 46 other necks all have 1 of the 8 different decoration units listed in Table 4 . In the majority of cases, necks are entirely covered with the same decorative unit (see Table 4, Type 1 and cf. Figure 8, n०1-4). Otherwise, they have a set of peripheral bands alternating decorated and undecorated surface (cf. Figure 9, $\mathrm{n}^{\circ} 2-4,8-9$ and Figure 10, $\mathrm{n}^{\circ} 1-2$ ) or more rarely peripheral bands alternating two different decoration patterns (cf. Figure $9, \mathrm{n}^{\circ} 6$ ). For small neck fragments, it is rather difficult to establish whether they are entirely covered with the same decoration or have peripheral bands (e.g. Figure 9, n ${ }^{\circ}$, 5, 7 and 10). Only a few sherds represent neck/shoulder junctions (cf. Figure 8, $\mathrm{n}^{\circ} 4,7-8$; Figure 9, $\mathrm{n}^{\circ} 4$ and 6; Figure 10, $\mathrm{n}^{\circ} 1$ ). The neck decoration can extend to the shoulder (cf. Figure 8, $\mathrm{n}^{\circ} 4$ and 8; Figure 9, $\mathrm{n}^{\circ} 6$ ). It can also stop on the boundary between neck and shoulder (cf. Figure $8, \mathrm{n}^{\circ} 7$; Figure 10, $\mathrm{n}^{\circ} 1$ ) and be separated by one or more horizontal lines reinforcing this limit (cf. Figure 10, $\mathrm{n}^{\circ} 1$ ).

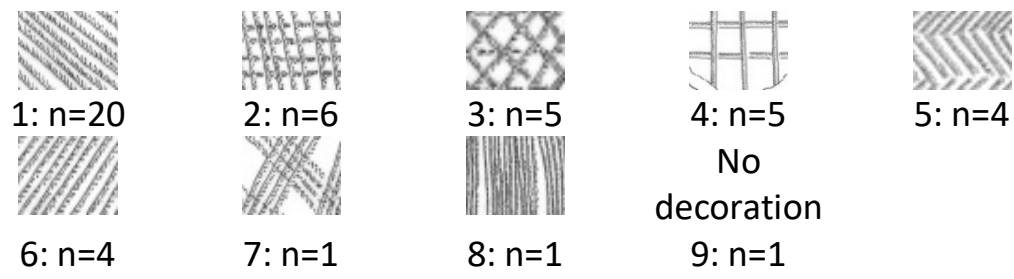

Table 4: Kitala Group, 9 neck decorative units observed on 47 upper part sherds

The body of recipients is generally left undecorated. The $57.8 \%$ of undecorated sherds in our sample almost all belong to vessel bodies according to their profile. If sherds from the body are decorated, they are often covered with a characteristic pattern of comb traces crisscrossing down to the vessel's base (cf. Figure 11, $\mathrm{n}^{\circ} 5-7$ ) or of parallel comb traces (cf. Figure 10, $\mathrm{n}^{\circ}$; Figure 11, $\mathrm{n}^{\circ} 1-3$ ). Otherwise, a few sherds exhibit what seem to be horizontal bands alternating either crescent-shaped impressions or stick and comb tracings (cf. Figure $10, \mathrm{n}^{\circ} 6-8$ ). Still others display several rows of traced herringbone (not illustrated but see Figure $9, \mathrm{n}^{\circ} 7-10$ for a similar design).

As for the bases, some show the use of comb decoration (cf. Figure 11, n ${ }^{\circ} 1-3, n^{\circ} 5-7$ ). The use of such comb tracings seemingly covering the vessel body, either using parallel or crisscrossing motifs, is very characteristic of Kitala production. A single neck is decorated using such crisscrossing comb tracing (cf. Figure 10, $\mathrm{n}^{\circ} 3$ ). One vessel has been decorated on the lower part of its body with comb drawings forming multi-linear festoons (cf. Figure 11, $\left.n^{\circ} 4\right)$. 


\section{Comparative account of Kitala ware}

After the detailed description of Kitala ware in the preceding section, we put it in a comparative perspective in this section. In $\S 4.1$, we compare Kitala ware with the pottery group to which it is most closely related in terms of chronology, geographical spread and typology, i.e. Kay Ladio ware. The latter is attested in the excavated assemblages of the Kindu, Mantsetsi, Sakuzi, and Sumbi sites in the Kongo Central province (de Maret 1972; Clist 1982; Gosselain 1988; de Maret 1990; Clist et al. 2019b). In §4.2, we discuss Kitala ware with reference to Gombe ware from the Kinshasa region, which is roughly contemporaneous.

\subsection{A comparison of the main characteristics of Kitala and Kay Ladio wares}

Kitala ware is a ceramic group mostly consisting of vessels with a closed shape. We distinguish between pots and jars based on the opening diameters and between types $\mathrm{A}, \mathrm{B}$, and $\mathrm{C}$ on the basis of the neck morphology (cf. §3.7). Kay Ladio ware has exactly the same shape categories. Open vessels are much more rare in Kitala ware as they are in Kay Ladio ware. However, the types of recipients with an open shape are much more diverse for Kay Ladio than for Kitala, but this could be an artifact of the research. With the little excavated material available for Kitala, we could not measure diameter openings and really distinguish between types with very different opening sizes (but compare for instance Figure 9, $\mathrm{n}^{\circ} 7$ and 8). Another difference in terms of shape is the absence of convex-shaped bottoms in Kitala ware. These are present in Kay Ladio ware along with flat bases and bottoms.

As discussed in $\S 3.8$, Kitala potters used a limited set of only 8 decorative units, Kay Ladio producers had a much richer decorative repertoire, i.e. 23 units in total (cf. Table 5), including 7 attested on Kitala ware (Kay Ladio units 1, 3, 5, 6, 8, 15, 23). Kitala unit 7 has not been found on Kay Ladio ware. Undecorated necks sometimes occur in Kitala ware, but never in Kay Ladio ware.

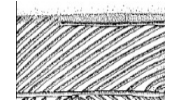

1

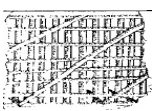

8

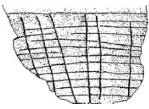

15

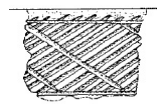

2

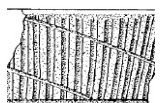

9

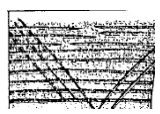

16

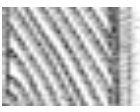

3

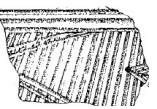

10

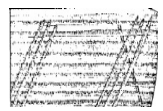

17

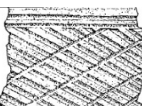

4

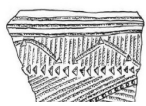

11

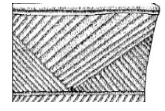

18

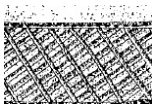

5

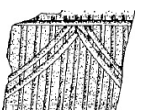

12

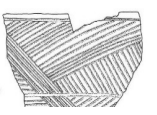

19

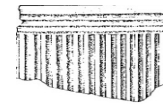

6

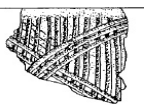

13

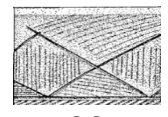

20

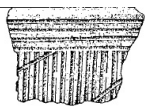

7

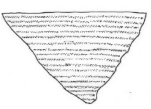

14

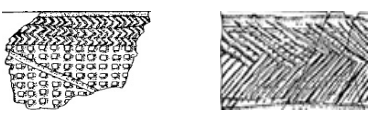

Revised paper for publication in the African Archaeological Review (June 20, 2019) 
Table 5: The 23 decorative units attested on necks of Kay Ladio Group ware

Kitala vessels are most often only partly covered with decoration, but they can also be fully covered as is evidenced by comb or stick traces on the base of some vessels (cf. Figure 11). This is also true for Kay Ladio ware, but these may also have geometrically-shaped decoration, which is entirely absent from Kitala ware.

The body of Kitala vessels is often decorated differently from their necks by a series of crisscrossing comb traces (cf. Figure 11, $\mathrm{n}^{\circ} 5-7$ ). These form very characteristic units that do not exist in Kay Ladio ware. Several Kitala vessels have a segmented organization of their decoration in the sense that the decorative units are not contiguous on the surface (cf. Figure 9, $\mathrm{n}^{\circ}$ 2, 4 and 9; Figure 10, $\mathrm{n}^{\circ} 1,2$ and 7). This feature is also unknown in Kay Ladio ware. Kitala pottery does not have limits between decorative units set up on the neck and on the shoulder of pots which is quite characteristic of Kay Ladio productions. Also decoration of the lip or the internal and external surfaces immediately below the lip, which we have observed on a small number of Kitala vessels (cf. Figure 9, $\mathrm{n}^{\circ} 1-6$ ), is absent from Kay Ladio pottery. The use of crescent-shaped stick impressions, forming large decorative patterns (cf. Figure 10, $\mathrm{n}^{\circ 5-6)}$, is also an originality of Kitala ware. However, several decorative Kitala elements may be inspired by Kay Ladio ware. For example, irregular alignments of stick impressions under the lip or at the top of the neck (cf. Figure 10, $\mathrm{n}^{\circ} 4$ ) are reminiscent of similar sets in Kay Ladio ware (cf. sets 2 and 3 in Table 6). Beveled lips, frequent in Kitala ware, are also present in large numbers in Kay Ladio ware (27\% in Sakuzi, 34\% in Kindu).

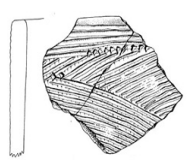

1

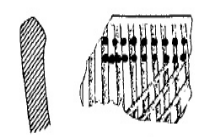

2

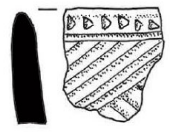

3

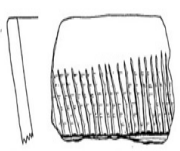

4

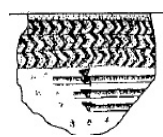

5

Table 6: Decorative units positioned under the lips of Kay Ladio ware

In terms of shaping, one of the techniques identified for both Kitala ware and Kay Ladio ware is coiling. The Kitala vessels are thicker than the Kay Ladio ones, up to $12 \mathrm{~mm}$ for Kitala, and only $8 \mathrm{~mm}$ to $10 \mathrm{~mm}$ for Kay Ladio. The 5 Kitala clay recipes are coarser and quite different from the 5 described for Kay Ladio ware described in Clist et al. (2019b) and compared in Table 7.

\begin{tabular}{|l|c|l|l|l|l|}
\hline $\begin{array}{l}\text { Group and } \\
\text { recipe number }\end{array}$ & $\begin{array}{c}\text { Section } \\
\text { type }\end{array}$ & Temper diameter & $\begin{array}{l}\text { Temper } \\
\text { density }\end{array}$ & $\begin{array}{c}\text { Temper } \\
\text { sorting }\end{array}$ & Temper types \\
\hline
\end{tabular}

Revised paper for publication in the African Archaeological Review (June 20, 2019) 


\begin{tabular}{|c|c|c|c|c|c|}
\hline KL1 & 2 & $0.5-1 \mathrm{~mm}$, rarely 2 & $10 \%$ & Good & Laterite, white minerals, mica \\
\hline KL2 & 2 & $0.5-2 \mathrm{~mm}$ & $5 \%$ & Good & $\begin{array}{l}\text { Laterite, sericite, \& various } \\
\text { rocks }\end{array}$ \\
\hline KL3 & 2 & $0.5-3 \mathrm{~mm}$ & $10 \%$ & Average & $\begin{array}{l}\text { Laterite, sericite, \& various } \\
\text { rocks }\end{array}$ \\
\hline KL4 & 2 & $0.5-3 \mathrm{~mm}$ & $10 \%$ & Poor & $\begin{array}{l}\text { Quartzite, laterite, small black } \\
\text { components, and grog }\end{array}$ \\
\hline KL5 & 4 & $0.5-2 \mathrm{~mm}$ & $10 \%$ & Average & Sericite \\
\hline K1 & 2 & $0.5-3 \mathrm{~mm}$ & $20-30 \%$ & $\begin{array}{l}\text { Very } \\
\text { coarse to } \\
\text { coarse }\end{array}$ & $\begin{array}{l}\text { Minerals including quartz, } \\
\text { and plants }\end{array}$ \\
\hline K2 & 2 & $0.5-2 \mathrm{~mm}$ & $10-20 \%$ & Medium & $\begin{array}{l}\text { Minerals including quartz, } \\
\text { with small black components }\end{array}$ \\
\hline K3 & 2 & $\begin{array}{l}0.5-3 \mathrm{~mm} \text {, regularly } \\
\text { up to } 13 \mathrm{~mm}\end{array}$ & $30 \%$ & $\begin{array}{l}\text { Very } \\
\text { coarse }\end{array}$ & Minerals \\
\hline K4 & 2 & $0.5-1 \mathrm{~mm}$ & $10 \%$ & $\begin{array}{l}\text { Good to } \\
\text { medium }\end{array}$ & \\
\hline K5 & 2 & $0.5-1 \mathrm{~mm}, 3 \mathrm{~mm}$ & $20 \%$ & Good & \\
\hline
\end{tabular}

Table 7: Comparison between clay recipes from the Kay Ladio (KL) and Kitala (K) Groups

In sum, Kitala and Kay Ladio pottery clearly share several features in terms of vessel types, shaping and decoration. However, they manifest also quite some differences in these regards and also in terms of clay fabrics. In our view, the evidence suggests that the Kitala ware is derived from Kay Ladio ware. This is well in line with the chronology of the two pottery groups. According to our current knowledge, Kitala ware (calAD 230-524) emerges towards the end of the production period of Kay Ladio ware (calAD 30-475), and its distribution partly overlaps with the southern extension of Kay Ladio, i.e. to the south of the Congo River. While sharing several traits in terms of shape and decoration, Kitala has a more reduced corpus of decorative units than Kay Ladio, i.e. 9 vs. 23 units. Moreover, one decorative unit dominates in Kitala ware, i.e. $\mathrm{n}^{\circ} 1$ in Table 4 ( $42 \%$ of all decorations), while the Kay Ladio potters had a much more diversified catalog (cf. Table 5). Finally, the Kitala fabrics are much coarser than Kay Ladio (Table 7).

The hypothesis that Kitala ware derives from Kay Ladio ware is possibly reinforced by the discovery in 2015 of several sites south of the Congo River, more specifically north-west of Songololo (Clist et al. 2018d), which featured both typical Kay Ladio pottery and sherds which one would consider today as Kitala ware, i.e. Bu 2 \& 4 and Kazu 2 \& 4-5. At none of these sites Kitala ware was found in an archaeological context. All Kitala attestations are surface finds, but the site of Bu3 is still telling with regard to the successive chronologies of Kay Ladio and Kitala wares. The archaeological level of Bu3 contained only Kay Ladio ware, whereas on the surface the material originating from the layer dismantled by erosion contained a lot of Kay Ladio sherds, but also a significant number of Kitala ware (Clist et al. 2019a). If these Kitala sherds did not belong to the same layer as Kay Ladio, this would indicate that Kitala ware did indeed develop out of Kay Ladio ware. However, they may also have belonged to the same layer, which would mean that Kitala ware was a contemporary import.

Revised paper for publication in the African Archaeological Review (June 20, 2019) 
Another site south of the Congo River possibly containing Kitala ware is Mongo some 40 kilometers as the crow flies to the south-west of the site of Kitala (cf. Figure 12). Some of the sherds which de Maret (1972) identified as being "Group VI", which would later on become the "Ngovo Group" (de Maret 1986), are now to be considered as Kitala ware mainly on the basis of their crisscrossing decoration pattern (de Maret 1972: vol. 3, n³71 and maybe also $\left.n^{\circ} 367\right)$.

In sum, according to our current knowledge, which is still fairly limited, the seven sites having yielded Kitala ware so far (i.e. Bu 2 \& 4, Kazu 2 \& 4-5, Mongo, and Kitala itself) have fairly limited geographical distribution. All are situated along an west-east axis of roughly $150 \mathrm{~km}$ south of the Congo River (cf. Figure 13). North of the Congo River, it is absent from the area between the villages of Sumbi and Kinkenge, where M. Bequaert did extensive fieldwork in 1951, the KongoKing project team in 2015 (Clist et al. 2018g) and the BantuFirst project team in 2018 (Clist et al. 2019a). South of the river, it has not been found in the vicinity of the Kibula seminary in the territory of Songololo, where several sites with Kay Ladio ware have been discovered (Clist et al. 2018d). Finally, neither Kitala ware nor any other EIA ware has been uncovered during intensive and repetitive fieldwork on and around the site of Kindoki north of Kisantu (Clist et al. 2015b; Clist et al. 2018a) and on and around Ngongo Mbata near the Angolan border (Clist et al. 2015c; Clist et al. 2018c).

\section{Insert Figure 12 here}

\subsection{Kitala ware vs. other EIA pottery groups in the wider Lower Congo region}

In this section we compare Kitala ware with EIA pottery groups found in two other parts of the wider Lower Congo region, i.e. so-called "Herringbone Ware" and "Carinated Broadly Grooved Ware" (CBG) from the Kouilou River area in the Congo Republic to the north of the Kongo-Central Province and the area around Kinshasa to the northeast of it.

In the Republic of Congo, the only EIA sequence available is from the work of James Denbow on the Atlantic coast around the mouth of Kouilou River (cf. Denbow et al. 1988; Denbow 1990a, b, 2012; Denbow 2014). Following two distinct phases of what Denbow (2014: 61-62) calls the "Ceramic Late Stone Age", the EIA is characterized by two different pottery groups, i.e. "Herringbone Ware" (ca. 198 calBC-calAD 766; we only take into account here the 9 dates from the more extensive excavations at BP113 (6) and Kayes (3), because John Denbow (pers. comm.) considers them representing the time range more accurately than the two slightly older dates from the sites of Grey Sand and Tandou Yombi) and CBG (ca. calAD 253-585) (Denbow 2014: 56-58 (table 54.51), 64-66). Although Herringbone starts some centuries before Kay Ladio, the time ranges of Herringbone and CBG overlap to a large extent with those of Kay Ladio (calAD 30-475) and Kitala (calAD 250-524). However, their shapes, decoration units and the organization of decoration units closely resemble neither those of Kay Ladio nor those of Kitala. A manifest morphological difference concerns the bases of vessels (internal part). Most Herringbone and CBG pots have convex-shaped bases. Although certain Kay Ladio pots do have convex-shaped bottoms 
(internal part), they are exclusively flat-based, as is the case for later Kitala ware and earlier Ngovo ware. The only clear morphological parallel are beveled rims, which are frequent in both Kay Ladio and Kitala wares as well as in some "Herringbone" assemblages, for instance at the BP 113 and Kayes sites (Denbow 2014: 111, 118). For the time being, it is hard to judge whether this feature is a shared inheritance or an independent development. As for decoration, herringbone is a shared feature, but not at all in equal proportions. Only few Kitala sherds are decorated by simple traced herringbone (only 3 items or $6 \%$ of the decorated subset) or multiple traced herringbone (only 1 item or $2 \%$ of the decorated subset). In Herringbone Ware, as its name indicates, this decoration type is much more predominant. Moreover, traced simple herringbone is also occasionally attested in Kay Ladio ware of the Sakuzi site (see above Table 5, unit 23), and simple and multiple traced herringbone sporadically in earlier Ngovo ware (Clist 1982: 136-137; de Maret 1986: 115, 117). In other words, herringbone decoration occurs in the Kongo Central Province since the first pottery traditions, but prevails in none of them and cannot be considered as distinctive as it is for Herringbone Ware. As such, it does not seem to be a feature that allows establishing a firm historical relationship, either genealogically or contact-induced, between the EIA wares east of Matadi and those from the Kouilou mouth area. A final resemblance between the EIA pottery of both regions is the presence of talc in the fabrics. It is reported for CBG ware as giving "the vessels a very "slippery" feeling" (Denbow 2014: 65). This is reminiscent of the fabrics of certain Kay Ladio vessels whose clays include sericite, i.e. recipes 2, 3 and 5 (Clist et al. 2019b), though they are earlier than CBG pottery. In sum, we consider Kay Ladio and Kitala wares to be clearly distinct from the known EIA wares on the Atlantic coast of CongoBrazzaville.

As for the Kinshasa area, pottery roughly contemporaneous with Kay Ladio ware (calAD 30-475) and Kitala ware (calAD 230-524), has been found in the upper levels of the Gombe site in Kinshasa (de Maret \& Stainier 1999). Its chronology is currently determined on the basis of three thermoluminescence dates bracketed between calAD 205 and 450 (Clist 2018; Clist et al. 2018e). This so-called "Gombe Type" pottery has been found in Kinshasa and its surroundings. Its identification is mainly based on its clay and 'temporarily' named Gombe Type: "due to the bad state of conservation of these sherds, their tentative classification is essentially based on clay aspect" (de Maret \& Stainier 1999: 484). Pottery with this specific clay was discovered at the sites of Citas, Gombe and Lemba within the present-day metropole of Kinshasa and on the nearby island of Mimosas on the Congo River (de Maret \& Stainier 1999: 485-486). In Lemba, H. Van Moorsel collected 17 intact vessels, 2 of which would belong to the "Gombe Type" (de Maret \& Stainier 1999: 485). In Citas, H. Van Moorsel discovered 5 intact pots, all of which have been attributed to "the Gombe Type" (de Maret \& Stainier 1999: 486). On the island of Mimosas, $7 \mathrm{~km}$ downstream from central Kinshasa, H. Van Moorsel collected 27 intact recipients, nearly half of which would be very close to the "Gombe Type" (de Maret \& Stainier 1999: 486). The finds of numerous intact recipients in these different sites point towards burial sites.

As for the Gombe site itself, drawings and photographs of pottery are available in several publications (Bequaert 1938: plate XIII; Cahen 1981: 130-132, Figures 2 and 3; de 
Maret \& Stainier 1999: 482-483, Figures 4 and 5, drawings 1-3). They show pottery with flat bases and bottoms (some exceptional convex bottoms notwithstanding), which are decorated with wide horizontal strokes of crisscross or incised traces on the necks. These decorations sometimes extend to the shoulder and the top of the body, but never to the base of the vessel. The lips are flat, convex or slightly thickened, but neither beveled nor decorated. The broad horizontal lines of decoration, which are recurrently found on pottery from Gombe (de Maret $\&$ Stainier 1999: 482-483, Figure 4, $\mathrm{n}^{\circ}$ 2, 7-10, Figure 5, $\left.\mathrm{n}^{\circ} 1-2\right)$, also figure on Kitala ware from Bu3 about $210 \mathrm{~km}$ to the southwest (Clist et al. 2018d: 191, Figure 14.4, $\mathrm{n}^{\circ} 8,10-11$ ). Apart from this specific decorative feature, EIA pottery from the Gombe site bears little resemblance to Kitala ware. This is not true for the intact recipients found on other sites of the Kinshasa area associated with Gombe, especially those from Mimosas Island, which are the best documented.

Several vessels found on the island of Mimosas are quite different from the EIA pottery from the Gombe site and manifest many more resemblances with Kitala ware both in terms of shape and decoration. Eggert (1986: 279-280) provides illustrations of six pots from Mimosas Island. All of them have flat bottoms. The lips of some vessels are decorated with short incisions as on Kitala ware (his Figure 8, $\mathrm{n}^{\circ} 1$ and Figure 9, $\mathrm{n}^{\circ} 1-3$ ), but they do not have beveled lips as often found on Kitala vessels. The inner and outer surfaces immediately below the lip are decorated on one vessel (his Figure 9, $\mathrm{n}^{\circ} 1$ ). A semi-covering decoration may extend to the neck and the shoulder, and sometimes to the top of the body (his Figure 8, $\mathrm{n}^{\circ} 2$ and 3), or cover the vessel surface down to the base of the pot, either with crisscrossing comb tracings (his Figure 9, $\mathrm{n}^{\circ} 3$ ), or a segmented organization (his Figure 9, $\mathrm{n}^{\circ} 1$ and 2), giving way to a decorated strip adjoining the base of the vessel (his Figure 8, $\mathrm{n}^{\circ} 1$ ). These decoration types and their organization are also found on Kitala ware but not on pottery of the "Gombe Type".

Interestingly, similar Kitala features were also found on other vessels from Mimosas not published by Eggert (1986). Their reexamination in 2014 and 2015 in the collections of the archaeological museum of Kinshasa University pointed out that two pots are very similar the six published by Eggert (1986) in terms of clay, decoration units and organization of decoration units, one of them being a bowl. The other recipients from Mimosas island seem to belong to a distinct pottery group probably deposited at a different period: clear-colored clay, different temper elements and decoration limited to the top of the vessel.

Considering the correlations observed today between the intact pots from Mimosas Island and Kitala ware, it is perhaps time to reconsider the ${ }^{14} \mathrm{C}$ date obtained on this island from an archaeological layer excavated by $\mathrm{H}$. Van Moorsel "containing charcoal together with old potsherds in the humic layer above the fluviatile sand overlying the red sandstone blocks" (Gilot et al. 1965: 122). Although the feature is distinct from the context of the intact pots, this date fits with the chronology of the Kitala group: Lv-168: 1540+/-100 bp, calAD 340-765.

In sum, the EIA pottery from the Kinshasa area seems to be typologically more diverse than thought before. Its diversity cannot be resumed to one single "Gombe Type". Several of the intact pots found on what are presumably burial sites in the vicinity of the Gombe site, 
especially on Mimosas Island, appear to belong to a distinct pottery group. While the pottery from Gombe has little to do with Kitala ware, several of the vessels from Mimosas Island do have several features in common with pottery from Kitala both in terms of shapes and decoration. These correspondences are certainly not strong enough to consider the pottery from Mimosas Island as Kitala ware, but they definitely merit more in-depth research.

\section{Conclusions}

Kitala ware, which is dated for the time being between calAD 230 and 524, is closely related but still distinct from the earlier known Kay Ladio ware dated between calAD 30 and 475 . Kitala ware is called after the only site where it has been excavated so far from a wellestablished archaeological context. Apart from the Kitala site, surface surveys led to its identification in six other sites in the Kongo Central Province, all of them situated to the east of Matadi and south of the Congo River. Its chronology and geographical distribution as well as the in-depth analysis of the clay features, the shapes and the decoration patterns of its vessels indicate that Kitala ware is probably a regional variety of Kay Ladio ware, the earliest EIA pottery group of the Kongo Central Province. Both EIA pottery groups are clearly distinct from the province's earliest pottery group i.e. Ngovo ware, which precedes the arrival of iron metallurgy and is dated between 420 calBC and calAD 130. A comparison with other EIA pottery groups from the wider Lower Congo regions reveals that both Kay Ladio ware and Kitala ware are neatly distinct from the EIA pottery traditions further north, i.e. those discovered in the Kouilou River mouth area along the Atlantic Coast region of the Congo Republic. However, Kitala ware does have specific features in common with EIA pottery found in several burial sites within the Kinshasa area, especially on the Island of Mimosa. Some of the intact vessels found there are clearly distinct from the pottery that is typical of Gombe, the best-dated and best-documented site around Kinshasa, but share distinctive elements with Kitala ware in terms of shapes and decoration. In other words, during the EIA the Lower Congo region of Central Africa had more regional variation in ceramic production than known before. Nevertheless, we see also certain common features across the region, which beg for further study.

The producers of Kitala ware mastered iron metallurgy. Unlike the producers of preEIA Ngovo ware, they no longer used polished stone axes and hoes. Excavations at Kitala site uncovered a forge pointing to a separate smelting site that is yet to be discovered. Still very little is known about the subsistence of Kitala ware manufacturers. They lived in a natural environment of open deciduous woods with access to tree species characteristic of wooded savannahs, such as Bridelia spp., and gallery forests, such as Elaeis guineensis, whose charred endocarps are abundantly attested at the Kitala site. So far no evidence has been found for plant cultivation, let alone farming. However, the rich alluvial lands of the nearby Bombe River do have a huge agricultural potential, which is still exploited for farming today and may have attracted settlers to grow plants as early as the EIA. This needs further examination through dedicated archaeobotanical sampling. 


\section{Acknowledgments}

We wish to thank first and foremost Els Cranshof. She was part of the fieldwork team that discovered the Kitala site in 2014 (cf. Section 2.2) and was involved in KongoKing research until the end of the project in 2016. However, she left academia in the meanwhile and was no longer available to participate in the drafting of the current article. We also acknowledge the contribution to our research of Roger Kidebua and Clément Mambu Nsangathi (both staff of the Institut des Musées Nationaux du Congo) and Isidore Nkanu Tsatsa, all of whom participated in the excavations at the Kitala site and surveys in its vicinity. Furthermore, we thank Professor Philippe de Maeyer and his colleagues from the UGent Department of Geography for the development of the topographic maps, which were invaluable for our research in and around Kitala. Equally invaluable was the MA thesis of Eva Vergaert, which was carried out under the supervision of Professor Jean Bourgeois from the UGent Department of Archaeology in close collaboration with the UGent Department of Geography. Thanks equally go to Karlis Karklins of the Society of Bead Researchers (Ottawa, Canada) for his help with dating the blue glass bead, Dr. C. Robion-Brunner (TRACES laboratory, CNRS UMR 5608) for the time she invested in examining the iron processing remains from Kitala as well as Dr. Barbara Eichhorn (African Archaeology and Archaeobotany lab, Frankfurt University) for assisting Dr. Wannes Hubau (BantuFirst project team, Ghent University) with the flotation of archaeobotanical samples. Finally, we thank the staff of the Africa Museum in Tervuren, who provided us first class service to access the M. Bequaert archaeology collections curated there.

\section{Compliance with Ethical Standards:}

Funding: The KongoKing project (2012-2016) was an interdisciplinary and interuniversity research project funded by Starting Grant No. 284126 of the European Research Council. The project's archive is to be found on the www.kongoking.net website. Fieldwork and research for this article was financed through the KongoKing project. Its writing happened as part of the on-going BantuFirst project funded by a Consolidator's Grant ( $\left.n^{\circ} 724275\right)$ of the European Research Council (cf. http://www.bantufirst.ugent.be).

Conflict of Interest: The authors declare that they have no conflict of interest. 


\section{References}

Bequaert, M. 1938. Les fouilles de Jean Colette à Kalina (Léopoldville). Annales du Musée du Congo Belge, série 1, Anthropologie et Préhistoire, 1(2), 25-88.

Cahen, D. 1981. Contribution à la chronologie de l'âge du fer dans la région de Kinshasa (Zaïre). In Roubet, C., H.-J. Hugot \& G. Souville (eds.), Préhistoire africaine, mélanges offerts au Doyen Lionel Balout (pp. 127-137). Paris: Éditions A.D.P.F.

Cahen, D. and Mortelmans, G. 1973. Un site tshitolien sur le plateau des Bateke (République du Zaïre). Tervuren: Annales du Musée royal de l'Afrique centrale.

Clist, B. 1982. Etude archéologique du matériel de la mission Maurits Bequaert de 19501952 au Bas-Zaïre. mémoire de licence, Université libre de Bruxelles, Bruxelles.

Clist, B. 2005. Des premiers villages aux premiers européens autour de l'estuaire du Gabon : quatre millénaires d'interactions entre l'homme et son milieu. thèse de doctorat, Université libre de Bruxelles, Bruxelles.

Clist, B. 2018. Dates radiocarbones et leurs contextes. In Clist, B., P. de Maret \& K. Bostoen (eds.), Une archéologie des provinces septentrionales du royaume Kongo (pp. 51-55). Oxford: Archaeopress.

Clist, B., Bigohe, S., Mambu, C., Nkanu, S. and Bostoen, K. 2019a. The BantuFirst Project in the Kongo Central Province (DRC): Archaeological and Paleo-environmental Research from September to November 2018. Nyame Akuma, 91.

Clist, B., Cranshof, E., De Herdt, T., Kidebua, R., Matonda, I., Nkanza Lutayi, A., Zaid, B. and Bostoen, K. 2015a. Le projet KongoKing : Les prospections et fouilles menées en 2015 dans la province du Kongo Central (République Démocratique du Congo). Nyame Akuma, 84, 128-141.

Clist, B., Cranshof, E., de Maret, P., Kaumba, M., Kidebua, R., Matonda, I., Nkanza Lutayi, A. and Yogolelo, J. 2018a. Fouilles et prospections entre Kisantu et le fleuve Congo. In Clist, B., P. de Maret \& K. Bostoen (eds.), Une archéologie des provinces septentrionales du royaume Kongo (pp. 133-162). Oxford: Archaeopress.

Clist, B., Cranshof, E., de Schryver, G.-M., Herremans, D., Karklins, K., Matonda, I., Polet, C., Sengeløv, A., Steyaert, F., Verhaeghe, C. and Bostoen, K. 2015b. The Elusive Archaeology of Kongo Urbanism: The Case of Kindoki, Mbanza Nsundi (Lower Congo, DRC). African Archaeological Review, 32(3), 369-412.

Clist, B., Cranshof, E., de Schryver, G.-M., Herremans, D., Karklins, K., Matonda, I., Steyaert, F. and Bostoen, K. 2015c. African-European Contacts in the Kongo Kingdom (Sixteenth-Eighteenth Centuries): New Archaeological Insights from Ngongo Mbata (Lower Congo, DRC). International Journal of Historical Archaeology, 19(3), 464-501.

Clist, B., Cranshof, E., Kaumba, M., Matonda, I. and Kidebua, R. 2018b. Fouilles et prospections à l'est de l'Inkisi. In Clist, B., P. de Maret \& K. Bostoen (eds.), Une archéologie des provinces septentrionales du royaume Kongo (pp. 163-180). Oxford: Archaeopress.

Clist, B., Cranshof, E., Kaumba, M., Matonda, I. and Nkanza Lutayi, A. 2018c. Fouilles et prospections à l'ouest de l'Inkisi, région de Ngongo Mbata. In Clist, B., P. de Maret \& K. Bostoen (eds.), Une archéologie des provinces septentrionales du royaume Kongo (pp. 71132). Oxford: Archaeopress.

Clist, B., Cranshof, E., Matonda, I. and Kidebua, R. 2018d. Fouilles et prospections dans le territoire de Songololo. In Clist, B., P. de Maret \& K. Bostoen (eds.), Une archéologie des provinces septentrionales du royaume Kongo (pp. 189-204). Oxford: Archaeopress. 
Clist, B., de Maret, P. and Bostoen, K. 2018e. Les débuts de la céramique, de la sédentarisation et de la métallurgie. In Clist, B., P. de Maret \& K. Bostoen (eds.), Une archéologie des provinces septentrionales du royaume Kongo (pp. 45-50). Oxford: Archaeopress.

Clist, B., de Maret, P. and Bostoen, K. (eds.). 2018f. Une archéologie des provinces septentrionales du royaume Kongo. Oxford: Archaeopress.

Clist, B., Hubau, W., Tshibamba Mukendi, J., Beeckman, H. and Bostoen, K. 2019b. The Earliest Iron-Producing Communities in the Lower Congo Region of Central Africa: New Insights from the $\mathrm{Bu}$, Kindu and Mantsetsi Sites. Azania, t.b.a.

Clist, B. and Lanfranchi, R. 1992. Contribution à l'étude de la sédentarisation en République Populaire d'Angola. Leba,(7), 245-267.

Clist, B., Lopes, M., Barreira, J., Cranshof, E., Mirão, J., Karklins, K. and Bostoen, K. 2015d. Mission d'expertise archéologique, ville de Mbanza Kongo, République d'Angola, 8-20 Novembre 2015 (rapport de mission non publié).

Clist, B., Nikis, N. and Nkanza Lutayi, A. 2018g. Fouilles et prospections dans le territoire de Luozi. In Clist, B., P. de Maret \& K. Bostoen (eds.), Une archéologie des provinces septentrionales du royaume Kongo (pp. 205-213). Oxford: Archaeopress.

Coccato, A., Costa, M., Rousaki, A., Clist, B., Karklins, K., Bostoen, K., Manhita, A., Cardoso, A., Dias, C. B., Candeias, A., Moens, L., Mirão, J. and Vandenabeele, P. 2017. Micro-Raman Spectroscopy and Complementary Techniques (hXRF, VP-SEM-EDS, $\mu-$ FTIR, Py-GC/MS) Applied to the Study of Beads from the Kongo Kingdom (Democratic Republic of Congo). Journal of Raman Spectroscopy, doi 10.1002/jrs.5106.

Compère, P. 1970. La carte des sols et de la végétation du Congo belge et du Ruanda-Urundi : 25. Bas-Congo ; Notice explicative. Bruxelles: Publications de l'Institut National pour l'Etude Agronomique du Congo Belge (INEAC).

Cornelissen, E. 2018. L'industrie en quartz de l'Holocène ancien au Bas-Congo. In Clist, B., P. de Maret \& K. Bostoen (eds.), Une archéologie des provinces septentrionales $d u$ royaume Kongo (pp. 31-44). Oxford: Archaeopress.

da Piedade Jesus, M., da Silva Domingos Pom, S. L., Aparício, M. A. M., Lourenço, J. P., Cahango, N. R., Alexandre, F. J., Nsakala Nsenga, B., Caboco, E., Ndonga Mfuwa, M., Lussunzi Vita, M., Silva, T. I. F., Bango Suama, V., Fortunato, C. and Dorado Sanchez, N. 2016. Mbanza Kongo, vestiges de la capitale de l'ancien royaume du Kongo. Proposition d'inscription sur la liste du patrimoine mondial. Paris: UNESCO, https://whc.unesco.org/document/159684.

Da Silva Domingos, S. L. 2009. Les séries céramiques des amas coquilliers de la région de Luanda (Angola). Contribution à l'étude de la préhistoire récente angolaise. thèse de doctorat, Université de Toulouse-Le Mirail, Toulouse.

de Maret, P. 1972. Etude d'une collection de céramiques protohistoriques du Bas-Zä̈re. mémoire de licence, Université libre de Bruxelles, Bruxelles.

de Maret, P. 1986. The Ngovo Group: An Industry with Polished Stone Tools and Pottery in Lower-Zaïre. African Archaeological Review, 4, 103-133.

de Maret, P. 1990. Le "néolithique" et l'Age du Fer Ancien dans le sud-ouest de l'Afrique Centrale. In Lanfranchi, R. \& D. Schwartz (eds.), Paysages quaternaires de l'Afrique Centrale Atlantique (pp. 447-457). Paris: ORSTOM.

de Maret, P. and Stainier, X. 1999. Excavations in the Upper Levels at Gombe and the Early Ceramic Industries in the Kinshasa Area (Zaïre). In Smolla, G., F.-R. Herrmann, I. Schmidt \& F. Verse (eds.), Festschrift für Günter Smolla (pp. 477-486). Wiesbaden: Selbstverlag des Landesamtes für Denkmalpflege Hessen. 
de Matos, D., Senna-Martinez, J. C. and Martins, A. C. 2013. Neolithic Artifacts from Northern Angola: Revising the Data on an Ancient Collection at IICT. Paper presented at Colóquio Internacional "Ciência nos Trópicos: Olhares sobre o Passado, Perspectivas de Futuro", Lisboa.

Decapmaker, J. 1951. Les funérailles chez les Bakongo. Aequatoria, 81(3), 81-84, 125-128.

Delmoitie-Nicolaï, J., Ladmirant, H. and Lepersonne, J. 1972. Carte géologique du Zaïre. feuille S.6/14, Ngungu. Tervuren: Musée royal de l'Afrique central.

Denbow, J. 1990a. Congo to Kalahari: Data and Hypotheses About the Political Economy of the Western Stream of the Early Iron Age. African Archaeological Review, 8, 139-176.

Denbow, J. 1990b. Rapport préliminaire sur l'archéologie du littoral congolais : prospection et fouilles de la région du Bas-Kouilou effectués en 1988. Nsi, 7, 4-9.

Denbow, J. 2012. Pride, Prejudice, Plunder, and Preservation: Archaeology and the Reenvisioning of Ethnogenesis on the Loango coast of the Republic of Congo. Antiquity, 86(332), 383-408.

Denbow, J. 2014. The Archaeology and Ethnography of Central Africa. Cambridge: Cambridge University Press.

Denbow, J., Manima-Moubouha, A. and Sanviti, N. 1988. Archaeological Excavations Along the Loango Coast. Nsi, 3, 37-42.

Dupré, M.-C. and Pinçon, B. 1997. Métallurgie et politique en Afrique centrale. Deux mille ans de vestiges sur les plateaux Batéké. Gabon, Congo, Zaïre. Paris: Karthala.

Eggert, M. 1986. Imbonga und Lingonda: zur fruhesten Besiedlung des Zentralafrikanischers Regionwaldes. Beiträge zur allgemeinen und vergleichenden Archäologie, 6, 247-288.

Ervedosa, C. 1980. Arqueologia Angolana. Lisboa: Edições 70.

Gilot, E., Ancion, N. and Capron, P. C. 1965. Louvain Natural Radiocarbon Measurements III. Radiocarbon, 7, 118-122.

Gosselain, O. 1988. Sakusi: fouille d'un premier village du néolithique et de l'âge des métaux au Zaïre. mémoire de licence, Université Libre de Bruxelles, Bruxelles.

Heimlich, G. 2014. L'art rupestre du massif de Lovo (République démocratique du Congo). thèse de doctorat, Université Libre de Bruxelles / Université de Paris I PanthéonSorbonne, Bruxelles / Paris.

Heimlich, G. 2016. The Anthropology and History of Rock Art in the Lower Congo in Perspective. Antiquity, 90(353), 1270-1285.

Heimlich, G., Le Quellec, J.-L. and Mambu, C. 2018. Lovo, Rock Images, and Mythology in the Land of the Kongo. Journal of Social Archaeology, 18(1), 30-49.

Heimlich, G., Richardin, P., Gandolfo, N., Laval, E. and Menu, M. 2013. First Direct Radiocarbon Dating of the Lower Congo Rock Art. Radiocarbon, 55(2-3), 1383-1390.

Hubau, W., Tshibamba Mukendi, J., Clist, B., Bostoen, K. and Beeckman, H. 2018. L'évolution de la composition de la forêt dans la région du Bas-Congo (1800 bp présent). In Clist, B., P. de Maret \& K. Bostoen (eds.), Une archéologie des provinces septentrionales du royaume Kongo (pp. 19-30). Oxford: Archaeopress.

Karklins, K. and Clist, B. 2018. Les perles importées et locales. In Clist, B., P. de Maret \& K. Bostoen (eds.), Une archéologie des provinces septentrionales du royaume Kongo (pp. 337-348). Oxford: Archaeopress.

Latham, P. 2004. Useful Plants of Bas-Congo Province, Democratic Republic of the Congo. London: United Kingdom Department for International Development.

Lavachery, P. 1990. L'Âge de la Pierre Récent au Bas-Zaïre : étude du matériel lithique des missions Bequaert, 1950-1952 et de Maret 1973. Mémoire de Licence, Université Libre de Bruxelles, Bruxelles. 
Lebrun, J. and Gilbert, G. 1954. Une classification écologique des forêts du Congo.

Bruxelles, Belgique: Publications de l'Institut National pour l'Etude Agronomique du Congo Belge (INEAC).

Matonda, I., Cranshof, E., Mambu, C., Kidebua, R. and Bostoen, K. 2014. Le projet KongoKing : Prospections archéologiques et enquêtes ethnoarchéologiques dans la vallée de l'Inkisi et régions avoisinantes (Province du Bas-Congo, RDC). Nyame Akuma, 82, 5765.

Muya wa Bitanko Kamuanga, D. 1991. Âge de la Pierre Récent : Zaïre. In Lanfranchi, R. \& B. Clist (eds.), Aux origines de l'Afrique centrale (pp. 115-122). Libreville: Centres Culturels Français d'Afrique Centrale, CICIBA.

Orton, C., Tyers, P. and Vince, A. 1993. Pottery in Archaeology. Cambridge: Cambridge University Press.

Valdeyron, N. and Da Silva Domingos, S. L. 2012. Coquillages (beaucoup) et crustacés (un peu) : l'économie des populations littorales de la baie de Luanda (Angola), du début de notre ère jusqu'à la période actuelle. Palethnologie de l'Afrique, 4, 111-142.

Van Moorsel, H. 1968. Atlas de Préhistoire de la Plaine de Kinshasa. Kinshasa: Université Lovanium.

Vergaert, E. 2014. Teledetectie van het Kongo koninkrijk. Inventariserend en methodologisch onderzoek naar de bruikbaarheid van satellietbeelden en luchtfoto's in het archeologish onderzoek van het Kongo Koninkrijk. MA thesis, Universiteit Gent, Gent.

Weeks, J. H. 1914. Among the Primitive Bakongo. New York: Negro Universities Press. 


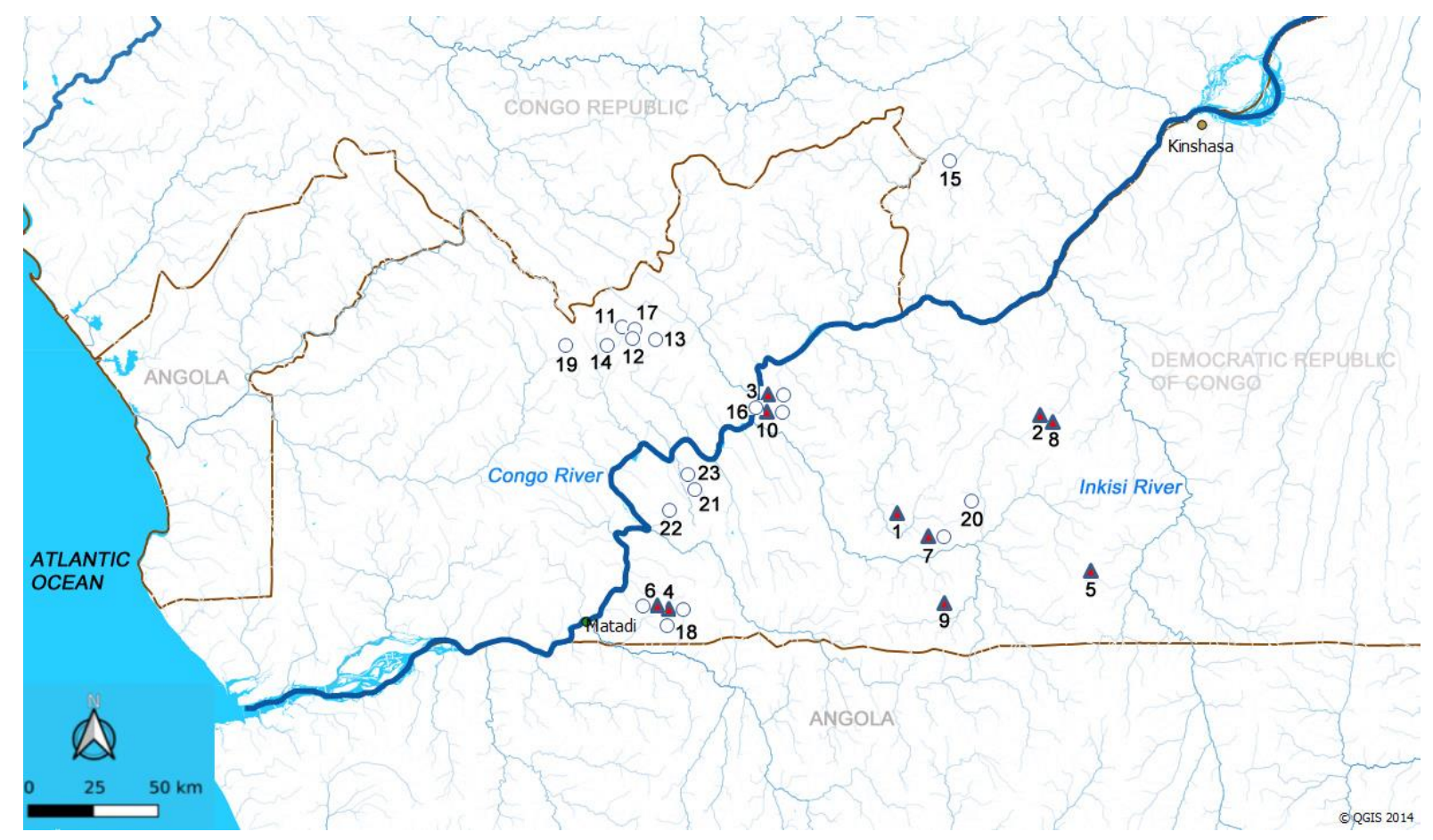

Figure 1 : Neolithic and Early Iron Age sites in the Kongo Central province of the DRC, Ngovo (triangles) and Kay Ladio Groups (circles).

Ngovo sites: Bangu (1), Dimba (2), Kay Ladio (3), Kimbala (4, aka Kongo dia Vanga), Kwimba (5), Mbanza 2 (6), Mongo (7), Ngovo (8), Ntadi Ntadi (9), Sakuzi (10).

Kay Ladio sites: Kay Ladio \& Kibula (3), Kimbala Solele (11), Kindu (12), Kinkenge (13), Kintadi les Lukuti (14), Nduizi (4, aka Kongo dia Vanga), Loukoko (15), Mabulu \& Kondo (16), Mantsetsi (17), Mongo (7), Nguemba (18), Sakuzi (10), Sumbi (19), Tumba (20), Bu3 (21), Kazul (22), Kulu (23). 


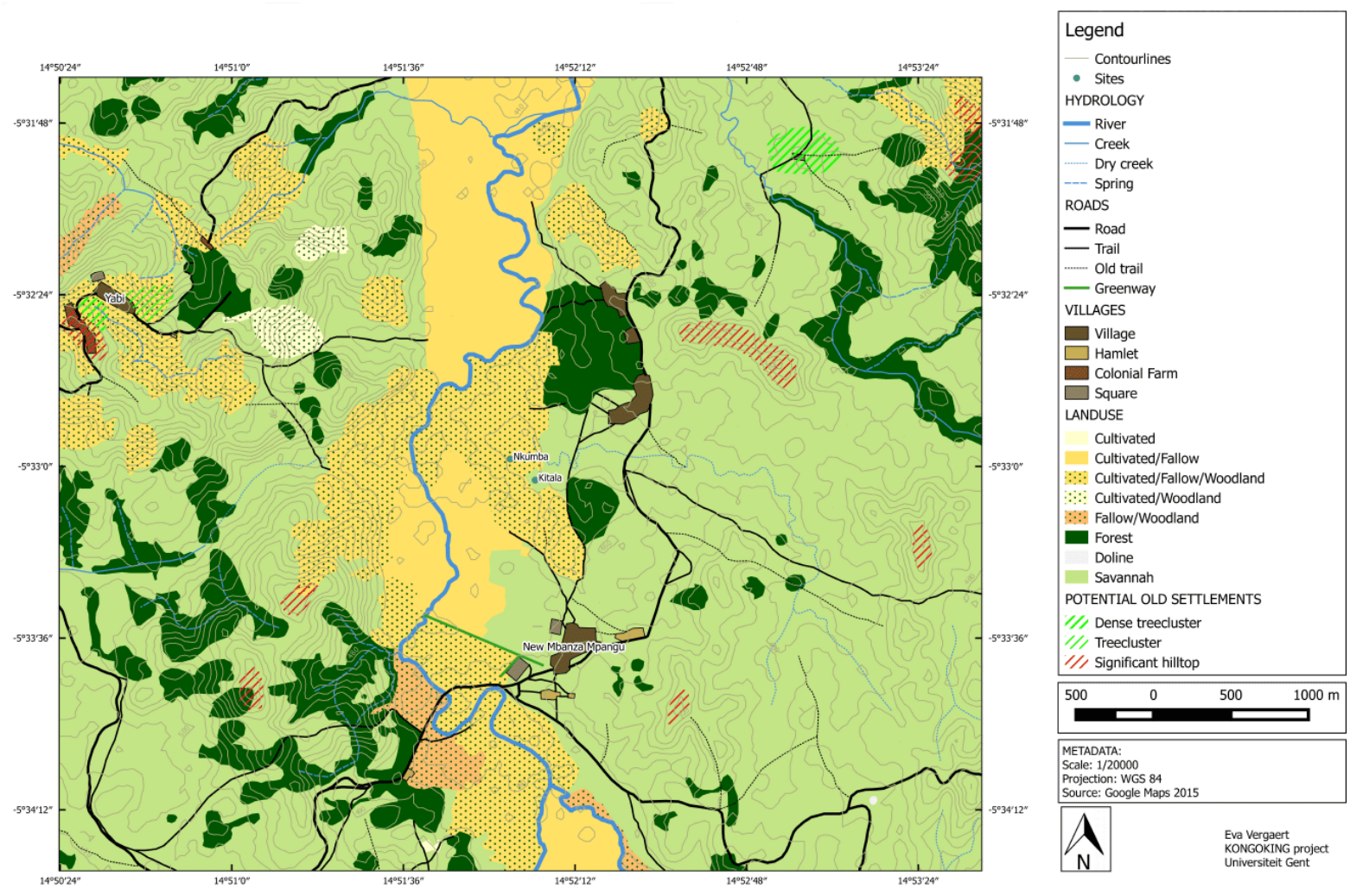

Figure 2: Land use around the Kitala site. The cultivated area in yellow is clearly associated to the Bombe river and its alluvial flats. The savannas (light green) clearly dominate the modern vegetation pattern with sometimes large patches of forest present (dark green). 


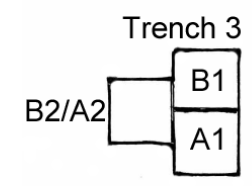

Trench 2
\begin{tabular}{|l|l|}
\hline B2 & B1 \\
\hline$A^{2}$ & A1 \\
\hline$A^{\prime} 2$ & \\
\hline
\end{tabular}

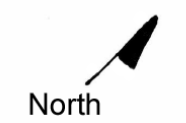

Trench 1
A1

Trench 6
\begin{tabular}{|l|l|}
\hline$A_{2}$ & $A^{\prime} 1$ \\
\hline$A^{\prime} 2$ & $A^{\prime} 1$ \\
\hline
\end{tabular}

\begin{tabular}{l}
$0 \quad 3 \mathrm{~m}$. \\
\hline
\end{tabular}

Kitala excavations 2014-2015

Figure 3 : Map of the Kitala excavation trenches 


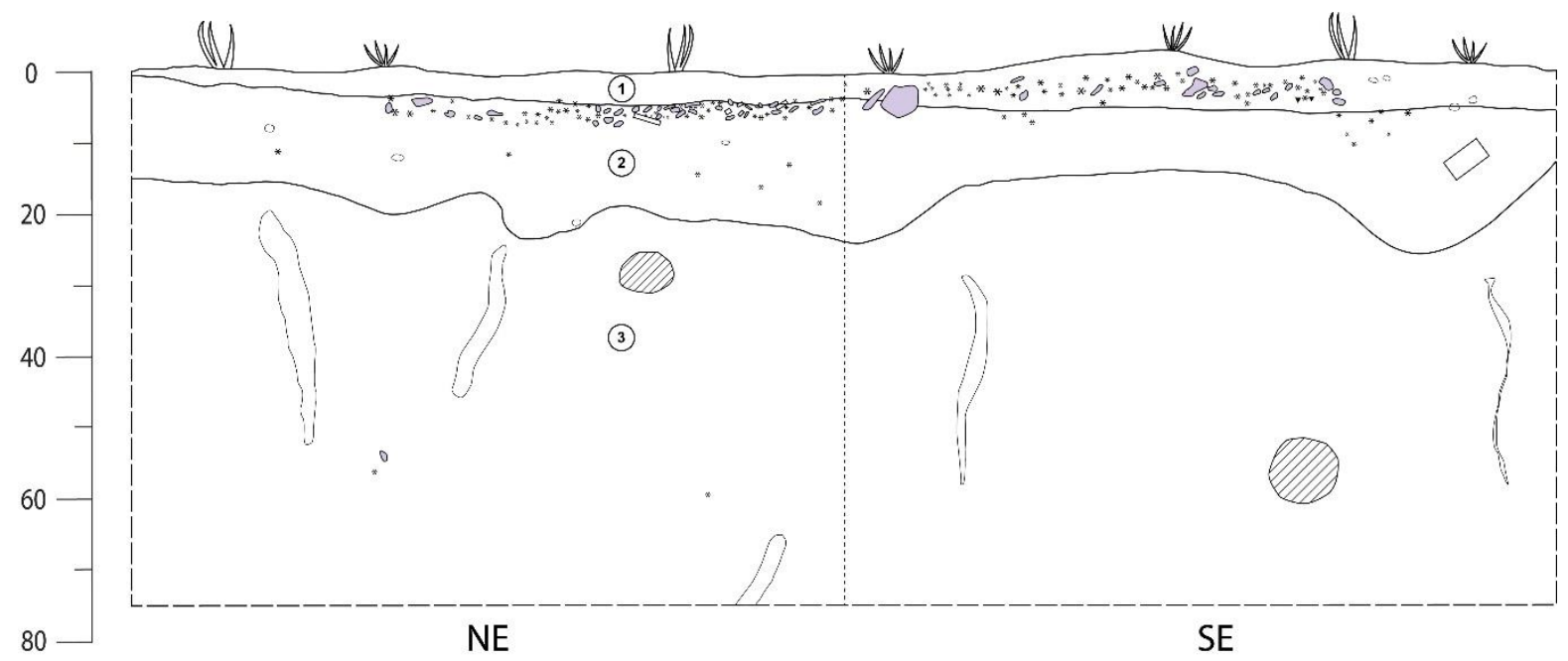

Figure 4: Kitala, 2014 excavation, trench 1, north-east and south-east profiles of A1 square. Black: charcoal; rectangle: potsherds; grey: stones; oblique dashes oriented to the right: bioturbations. 1: Humic layer. 2: Wet dark reddish brown clayey sand. 3: Brownish yellow clayey sand (profile by Els Cranshof) 


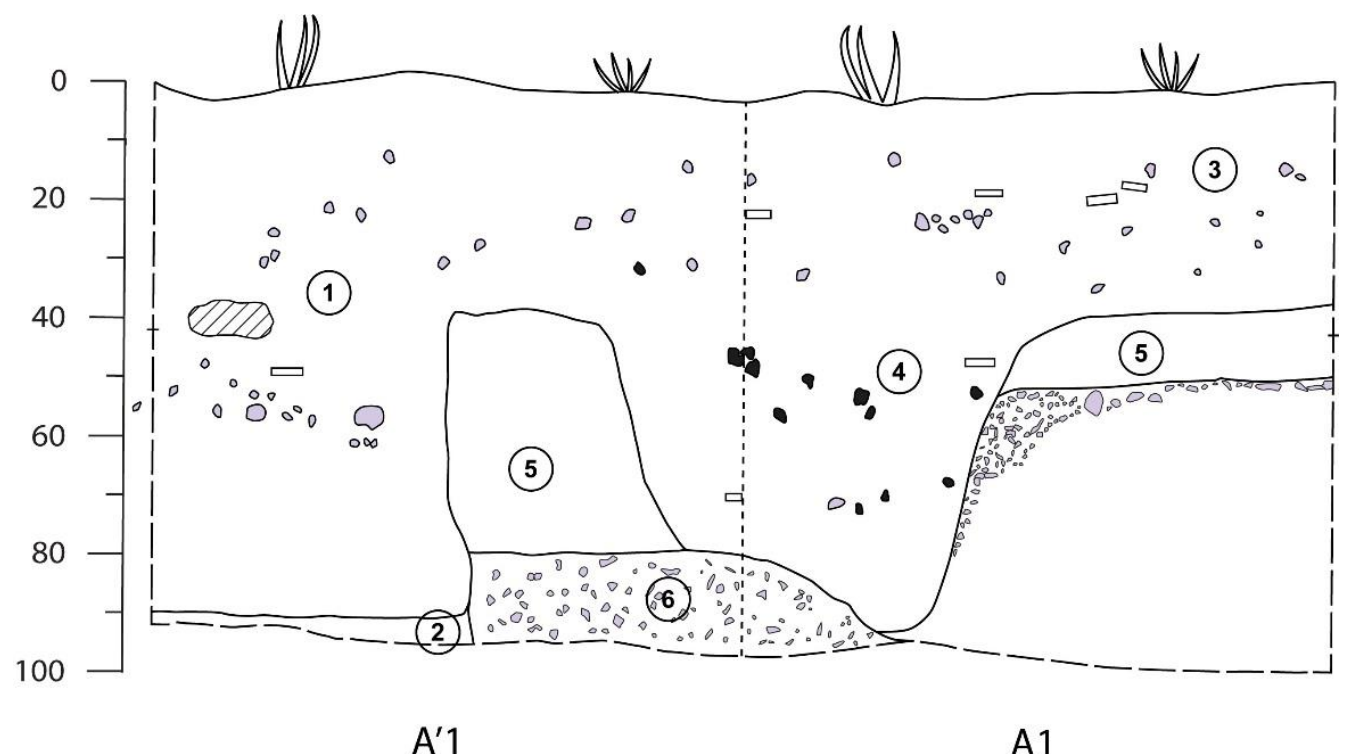

Figure 5: Kitala, 2015 excavation, trench 6, south-west profile, A'1 and A1 squares.

Black: charcoal; rectangle: potsherds; grey: stones; oblique dashes oriented to the right: bioturbations. 1-2: $19^{\text {th }}$ century grave fill; 3: Archaeological layer containing Kitala ware; 4: Filling of pit containing Kitala ware; 5: sandy-clay level; 6: cemented gravel. (Profile by Bernard Clist) 


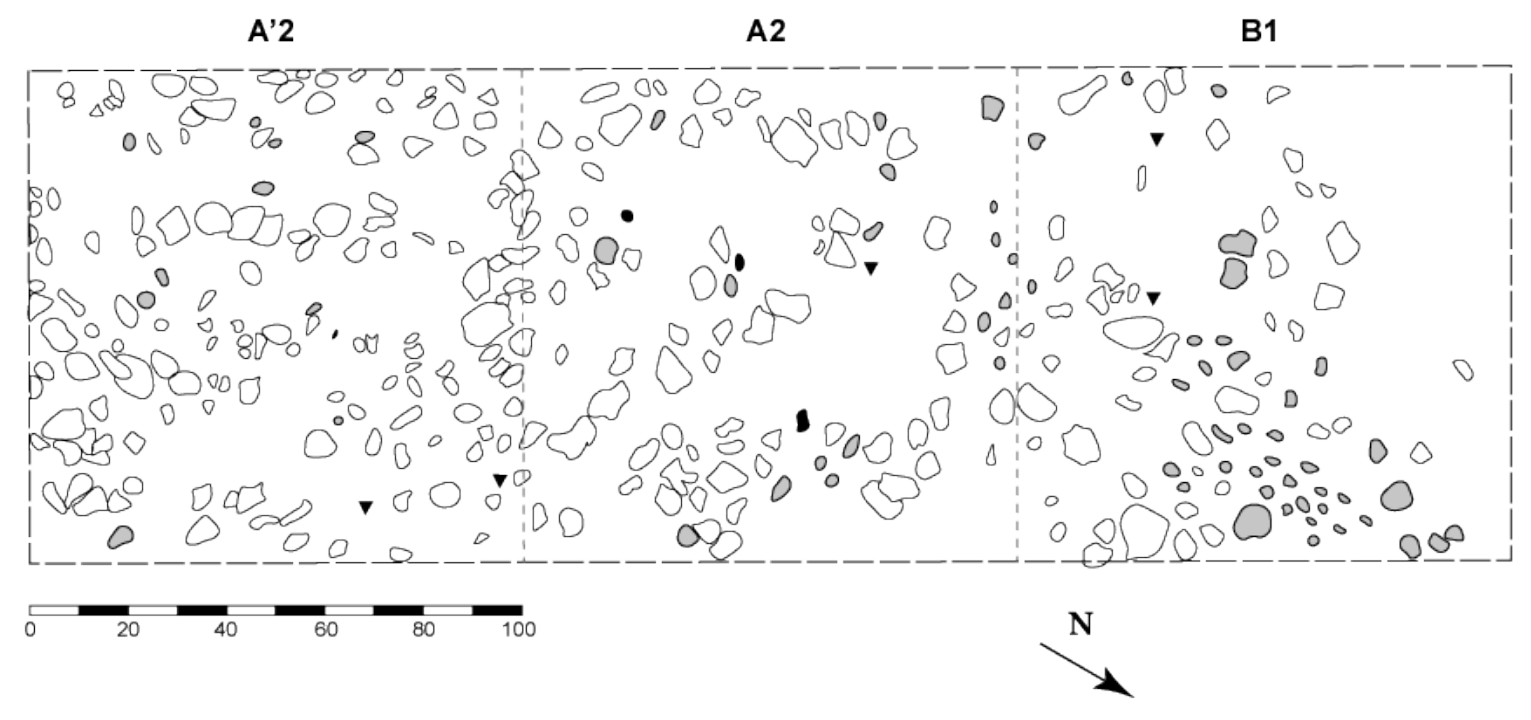

Figure 6: Kitala, 2015 excavation, trench 2, map of squares A'2-A2-B2 at -24 cm.

Black: charcoal; black triangle: iron slag; white objects: potsherds; gray: stones; oblique dashes oriented to the right: bioturbations. (Plan by Els Cranshof) 


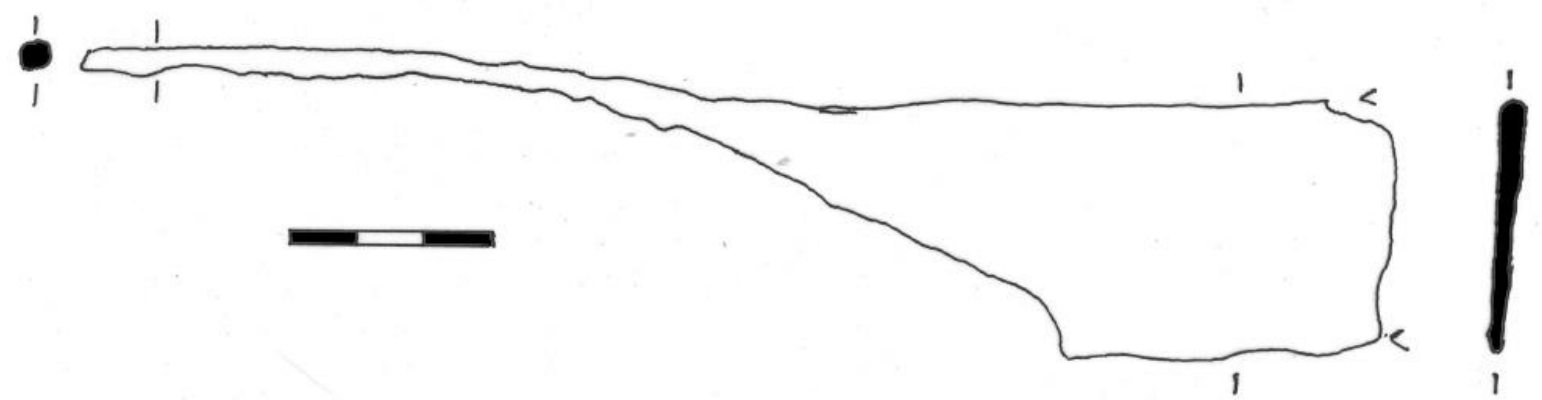

Figure 7: Fragment of an iron knife, trench 2, square B1, -24cm 

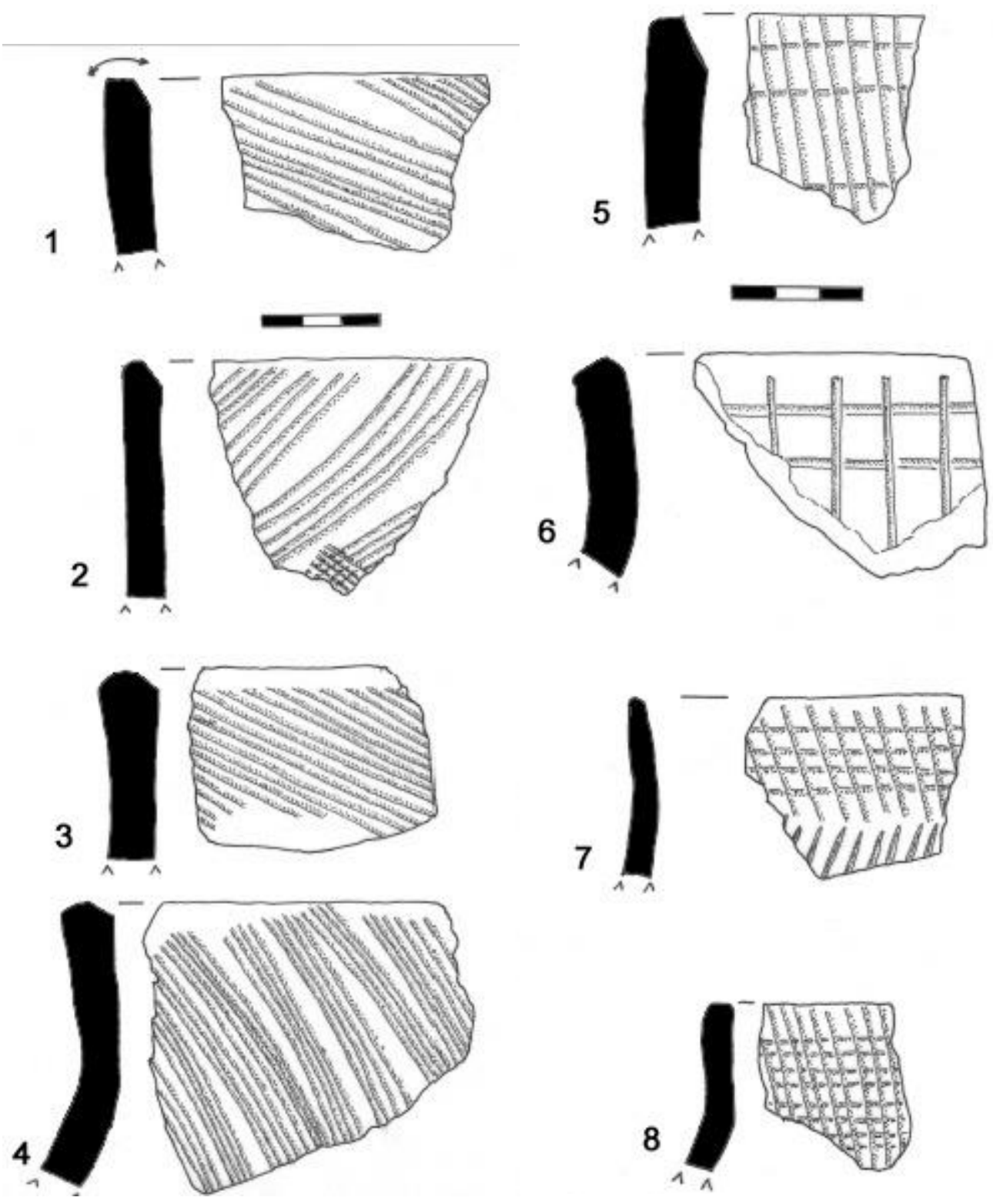

Figure 8: Necks decoration. 1: test pit 2, square A'2, -10/-20cm; 2: test pit 2, square A'2, 10/-20cm; 3: test pit 2, square A'2, -10/-20cm; 4: test pit 6, square A'1, -10/-20cm; 5: : test pit 2, square A'2, -10/-20cm; 6: test pit 6, square A'1, -10/-20cm; 7: test pit 2, square A2, 20/-30cm; 8: test pit 2, square A'2, -20/-30cm. 


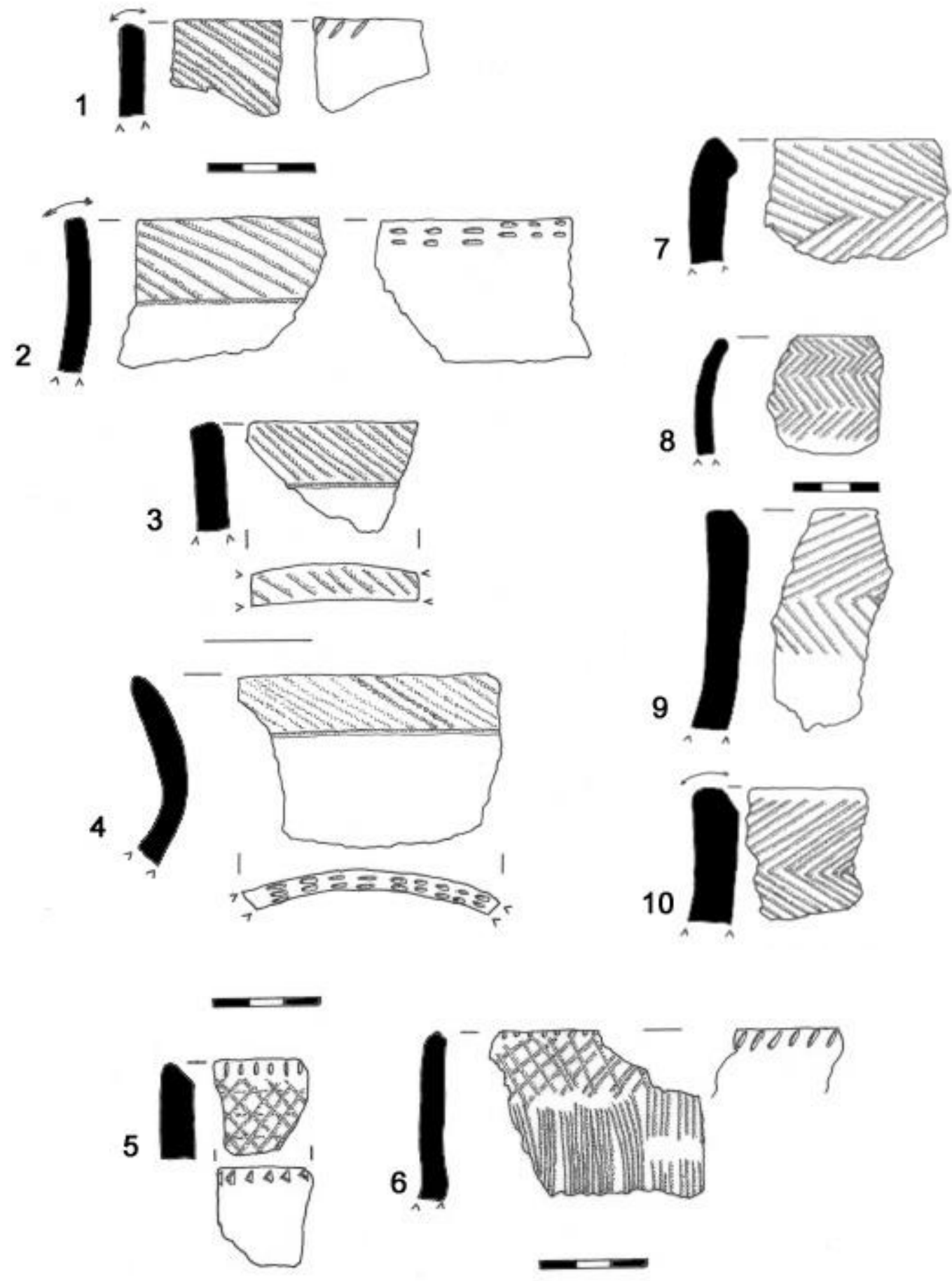

Figure 9: Lips and necks decoration. 1: test pit 6, square A'1, -20/-30cm; 2: test pit 6, square A'1, -20/-30cm; 3: test pit 2, square A'2, -10/-20cm; 4: test pit 6, square A'1, -10/-20cm; 5: test pit 3, squares A2-B2, -10/-20cm; 6: test pit 2, square B2, -30/-40 cm; 7: test pit 3, squares A2-B2, -40/-50cm; 8: test pit 2, square B1, -20/-30cm; 9: test pit 6, square A'1, -20/30cm; 10: test pit 6, square A'1, -20/-30cm. 


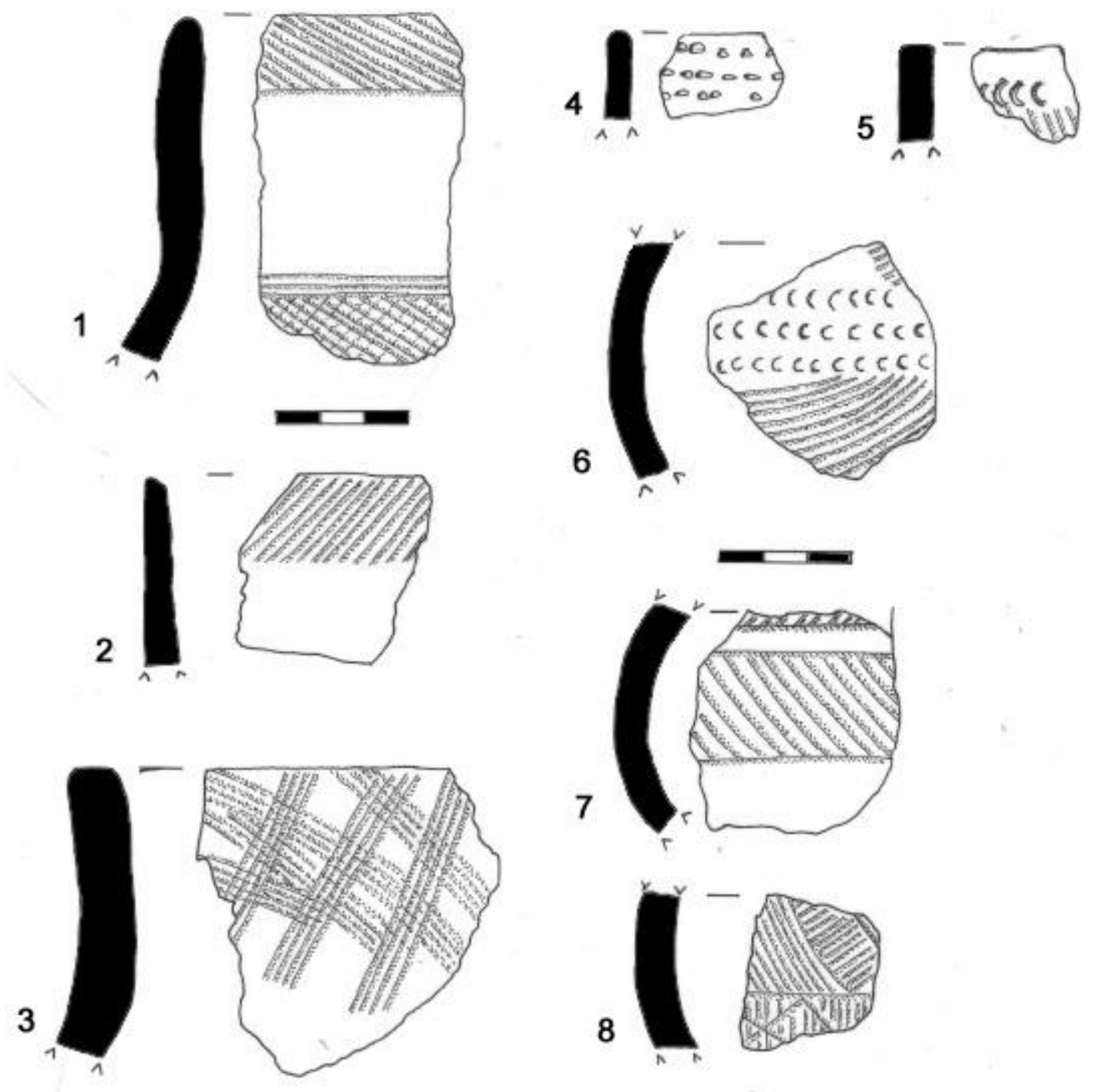

Figure 10: Neck and body decoration. 1: test pit 3, squares A2-B2, -10/-20cm; 2: test pit 3, squares A2-B2, -20/-30cm; 3: test pit 6, square A'1, -10/-20cm; 4: test pit 6, square A'1, 10/-20cm; 5: test pit 2, square A'2, -20/-30cm; 6: test pit 3, square A1, -10/-20cm; 7: test pit 2, square A2, -20/-30cm; 8: test pit 3, squares A2-B2, -20/-30cm. 

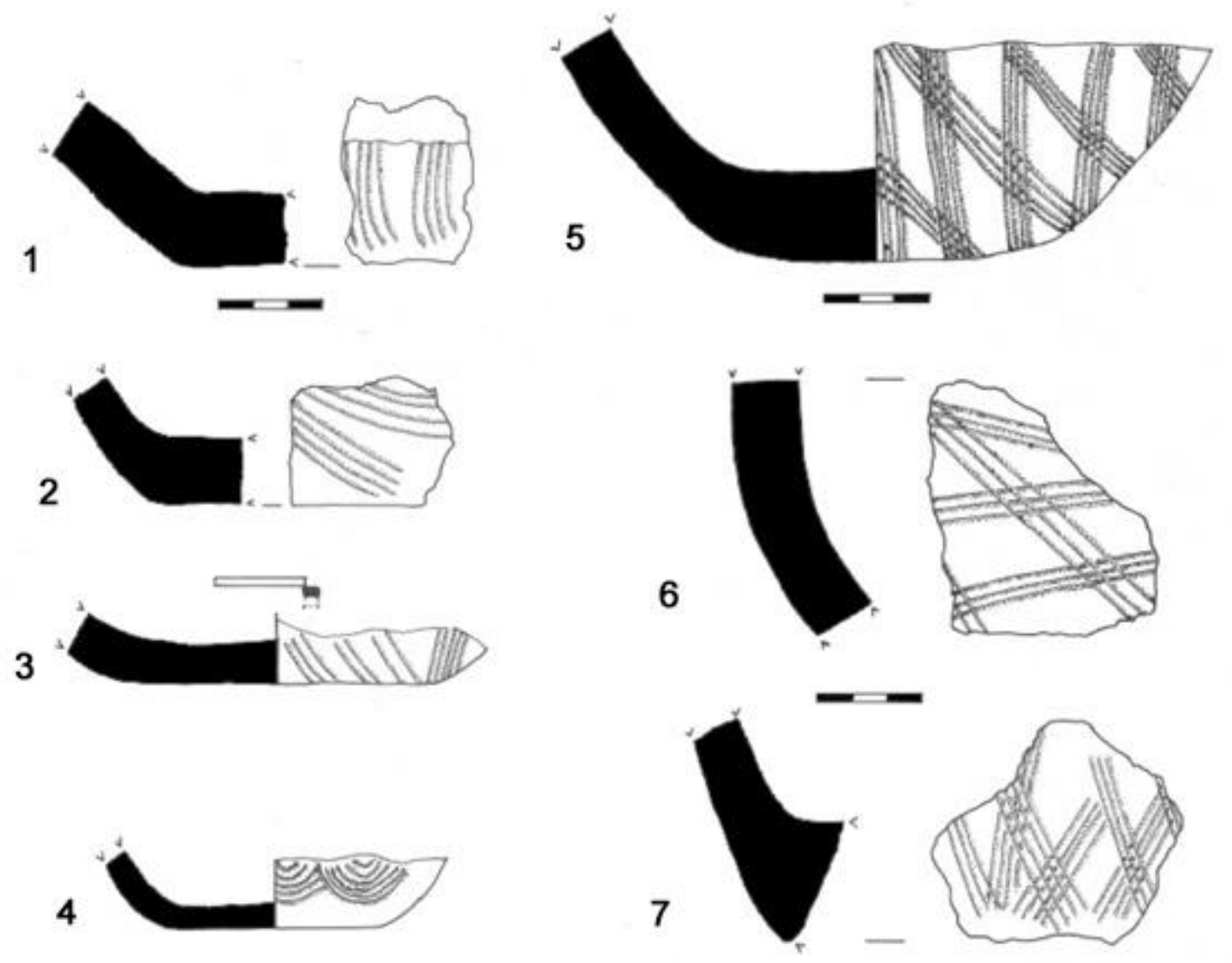

Figure 11, scale in centimeters: Pots bases. $N^{\circ} 1-3:$ Fragments from -20/-30cm with simple comb strokes (1: test pit 2, square B1; 2: test pit 6, square A'1; 3: test pit 2, square A2) ; $n^{\circ} 4$ : semi-circular comb strokes (test pit 2, square A’2, -20/-30cm) ; $n^{\circ} 5-7$ : criss cross comb tracings (5: test pit 2, square B2, -20/-30cm; 6: test pit 2, quare A'2, -20/-30 cm; 7: test pit 3, square $A 2,-10 /-20 \mathrm{~cm}$ ). 


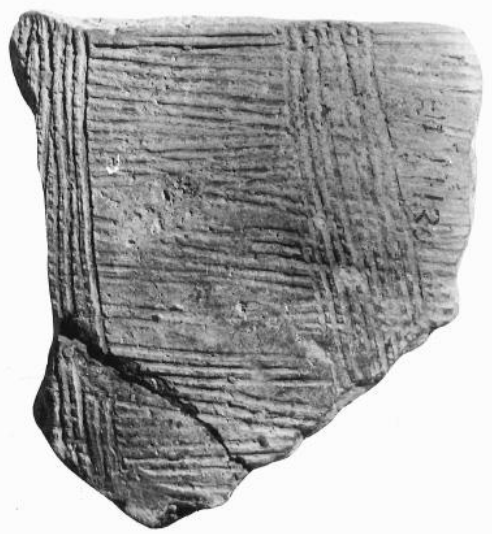

Mongo, ${ }^{\circ}$ MRAC 85227

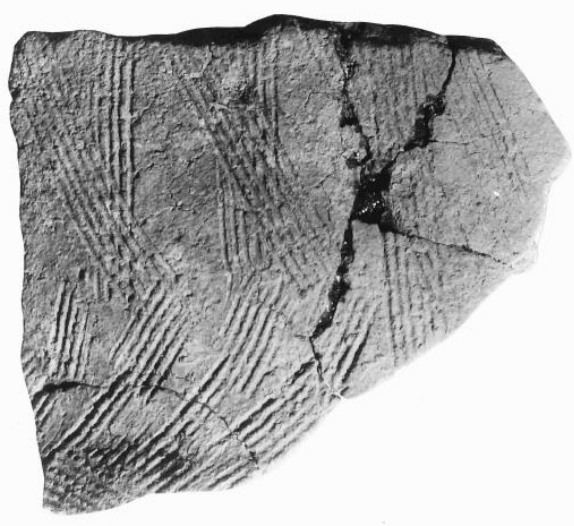

Mongo, $n^{\circ}$ MRAC 85231

Figure 12: Potsherds from the Mongo site illustrated in de Maret 1972, volume 3, n³67 (left) and 371 (right). 


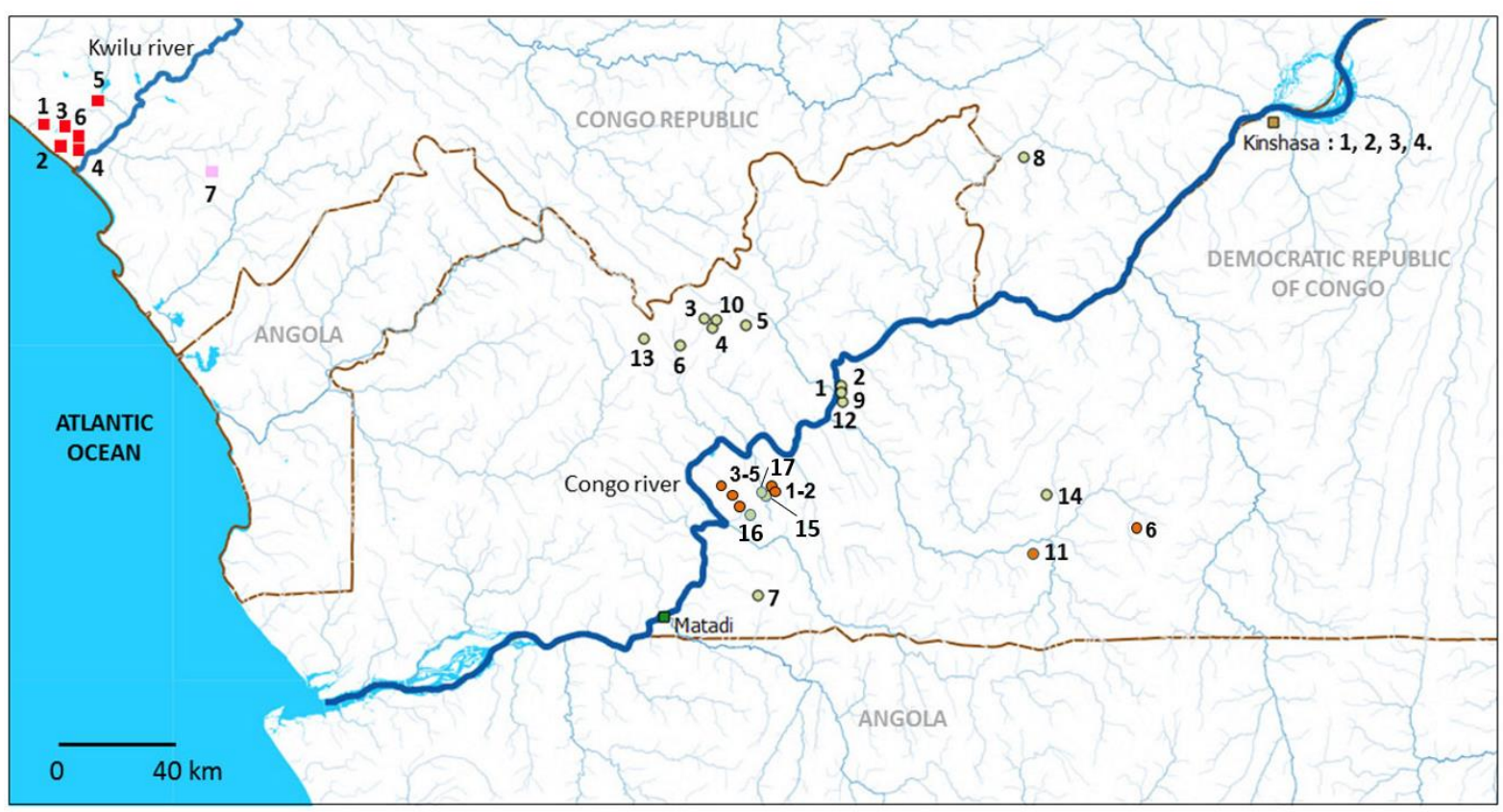

Figure 13 : Early Iron Age sites in the Kongo Central and Kinshasa provinces of the DRC and immediately surrounding areas in Angola and the Congo Republic.

Kay Ladio (green circles): 1- Kay Ladio, 2- Kibula, 3- Kimbala Solele, 4- Kindu, 5- Kinkenge, 6- Kintadi-lezLukuti, 7- Nduizi (aka Kongo-dia-Vanga), 8- Loukoko 1, 9- Mabulu and Kondo, 10- Mantsetsi, 11- Mongo, 12Sakuzi, 13-Sumbi, 14- Tumba, 15- Bu 3, 16- Kazu 1, 17- Kulu.

Kitala and Kitala related (orange circles): 1- Ви 2, 2- Ви 4, 3- Каzи 2, 4- Каzи 4, 5- Kazи 5, 6-Kitala, 11 - Mongo. "Gombe Type" in the Kinshasa area: 1-Citas, 2- Gombe, 3-Lemba, 4-Mimosas (île des).

Herringbone ware and Carinated Broadly Grooved Ware (red squares): 1- BP113, 2- Kayes, 3- Lake Ndembo, 4- Madingo Kayes, 5- Meningue, 6- Tandou Yombi,

Isolated Iron smelting site of Les Sarahs : 7. 